\title{
Vertical migration patterns of phytoflagellates in relation to light and nutrient availability in a shallow microtidal estuary
}

\author{
Nathan S. Hall*, Hans W. Paerl \\ Institute of Marine Sciences, University of North Carolina at Chapel Hill, Morehead City, North Carolina 28557, USA
}

\begin{abstract}
Physical and chemical vertical gradients in estuaries are often steep, with changes on the scale of $\mathrm{cm}$ to $\mathrm{m}$ strongly affecting a phytoplankter's exposure to limiting nutrients and light. Two diel field studies were conducted during June and July 2001 to establish how the composition and productivity of the phytoplankton are influenced by the vertical water column structure within the shallow, eutrophic, microtidal Neuse River Estuary, North Carolina, USA. During both studies, an upper photic mixed layer with low dissolved inorganic nitrogen (DIN) $(\sim 1 \mu \mathrm{M})$ lay above a sub-halocline, aphotic region with elevated DIN ( 2 to $5 \mu \mathrm{M}$ ). Phytoflagellates were dominant, and observed diel vertical migration (DVM) patterns are likely an important reason for their success in this N-limited system characterized by strong vertical separation of light and DIN resources. Integrated water column primary productivities during June and July were 15 and $113 \%$ greater, respectively, than expected for a vertically homogenous phytoplankton community. The high degree of productivity enhancement in July was due to daytime near-surface aggregation in response to low-light, overcast conditions. Displacements of flagellate populations during DVM were positively correlated with cell size, exposing larger cells to higher light and nutrient levels over the diel period. Since larger phytoplankton are generally less efficient at utilizing scarce resources, such vertical niche partitioning according to cell size should enhance community-level productivity. Interspecific variation in vertical migration patterns is an important trait of phytoplankton that promotes complementarity of resource utilization and contributes to the relationship between diversity and productivity within phytoplankton communities.
\end{abstract}

KEY WORDS: Phytoflagellate · Diel vertical migration • Estuary · Light · Nutrients · Primary productivity · Stratification

Resale or republication not permitted without written consent of the publisher

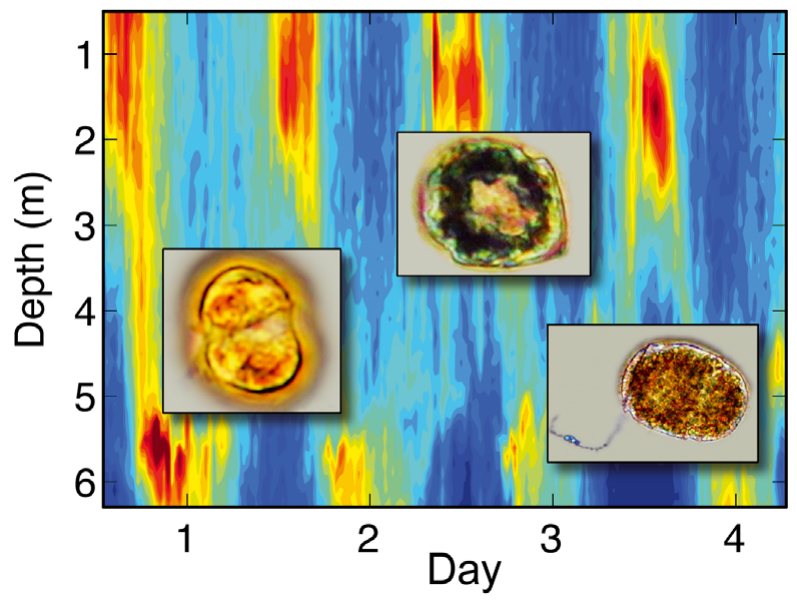

In vivo fluorescence profiles over $4 \mathrm{~d}$ in the Neuse River Estuary showing phytoflagellate diel vertical migrations (red: high abundance; blue: low abundance), and photomicrographs of common phytoflagellates (from left to right: Karlodinium veneficum, Scrippsiella trochoidea, Pheopolykrikos hartmanii).

Image: N. S. Hall and A. R. Joyner

\section{INTRODUCTION}

Phytoplankton vertical distribution is of central interest to phytoplankton ecologists because vertical gradients of light, nutrient concentrations, current velocities and turbulence are much steeper than horizontal gradients of these properties. These factors affect phytoplankton growth, survival and coexistence strategies (Margalef 1978, Fogg 1991). Among marine systems, some of the steepest vertical physical and chemical gradients are found in estuaries that are strongly salinity stratified. In these systems, depth distributions of phytoplankton cells are controlled by a number of interacting factors, including endogenous and environ- 
mentally cued swimming and buoyancy regulation (Kamykowski et al. 1998), vertical advection due to upwelling and/or downwelling, and turbulent mixing (Margalef 1978). Changes in the depth distribution of phytoplankton coupled with the steep physical and chemical gradients in estuaries can result in dramatic changes in light and nutrient availability over short time (s to d) and spatial (cm to m) scales. Evolutionarily, phytoplankton have developed diverse strategies to help regulate their distribution relative to the various vertical physical and chemical gradients in order to enhance growth and survival (Margalef 1978, Ganf \& Oliver 1982, Fogg 1991). For example, at the population level, coupling between the depth distribution of phytoplankton and vertical gradients of current velocities may decrease advective losses (Seliger et al. 1970, Anderson \& Stolzenbach 1985, Chang \& Carpenter 1985, Crawford and Purdie 1992). Additionally, mismatches in the vertical localization of phytoplankton and zooplankton patches can decrease grazing losses (Jones 1991, Salonen \& Rosenberg 2000). Despite the potential importance of these $z$-dimension gradients, relatively few studies have investigated the relationship between these gradients and phytoplankton community structure in shallow-water $(<10 \mathrm{~m})$ marine systems, with notable exceptions being Seliger et al. (1970), Anderson \& Stolzenbach (1985), Chang \& Carpenter (1985), Waters \& Mitchell (2002) and Handy et al. (2005). This is particularly true with respect to how the community responds to diel changes in light intensity via diel vertical migration (DVM) (Litaker et al. 1987). The present study was therefore undertaken to gain greater insight into how vertical gradients, particularly with respect to growth-limiting light and nutrient resources, influence phytoplankton community structure and productivity. The study itself was conducted in the Neuse River Estuary (NRE), North Carolina, USA, and encompassed 2 time-intensive diel field studies.
The NRE is a shallow-water (4 to $7 \mathrm{~m}$ ) microtidal estuary that receives freshwater primarily from the Neuse River and saltwater inputs from Pamlico Sound (Fig. 1). The phytoplankton community in this estuary is quite diverse, with diatoms, chlorophytes, cyanobacteria, dinoflagellates and cryptophytes all comprising important segments of the community under various conditions (Mallin et al. 1991, Pinckney et al. 1998). Diatoms lack motility and are generally negatively buoyant, requiring turbulence to maintain their position within the photic zone (Sournia 1982). Although some cyanobacteria effectively use gas vesicles to control their position in the water column (Paerl 1988), the picoplanktonic Synechococcus spp. that dominate the cyanobacteria of the lower NRE (Gaulke et al. 2010) lack gas vesicles necessary for vertical migration (Sournia 1982). In contrast, the dinoflagellates, cryptophytes and many of the chlorophytes are flagellated, with swimming speeds that allow for vertical migration when mixing is weak. DVM is a common migration pattern of flagellated phytoplankton, whereby cells swim to the welllit surface waters during the day and into deeper, usually more nutrient-rich waters at night (Eppley et al. 1968, MacIntyre et al. 1997). Aggregation at the pycnocline is another commonly observed vertical distribution pattern of motile organisms in stratified environments (Tyler \& Seliger 1981, Waters \& Mitchell 2002, Kononen et al. 2003), which, when the photic zone is deep enough, provides simultaneous access to light and nutrient resources (Klausmeier \& Litchman 2001).

Although the phytoplankton community is diverse, blooms in the NRE are nearly always comprised of flagellates of the classes Dinophycea, Cryptophycea or Raphidophyceae (Mallin et al. 1991, Pinckney et al. 1998, Rothenberger et al. 2009). At times, these blooms cause severe water quality problems such as decreased water transparency (Woodruff et al. 1999, Hall et al. 2008), bottom water hypoxia (Paerl et al. 1998)

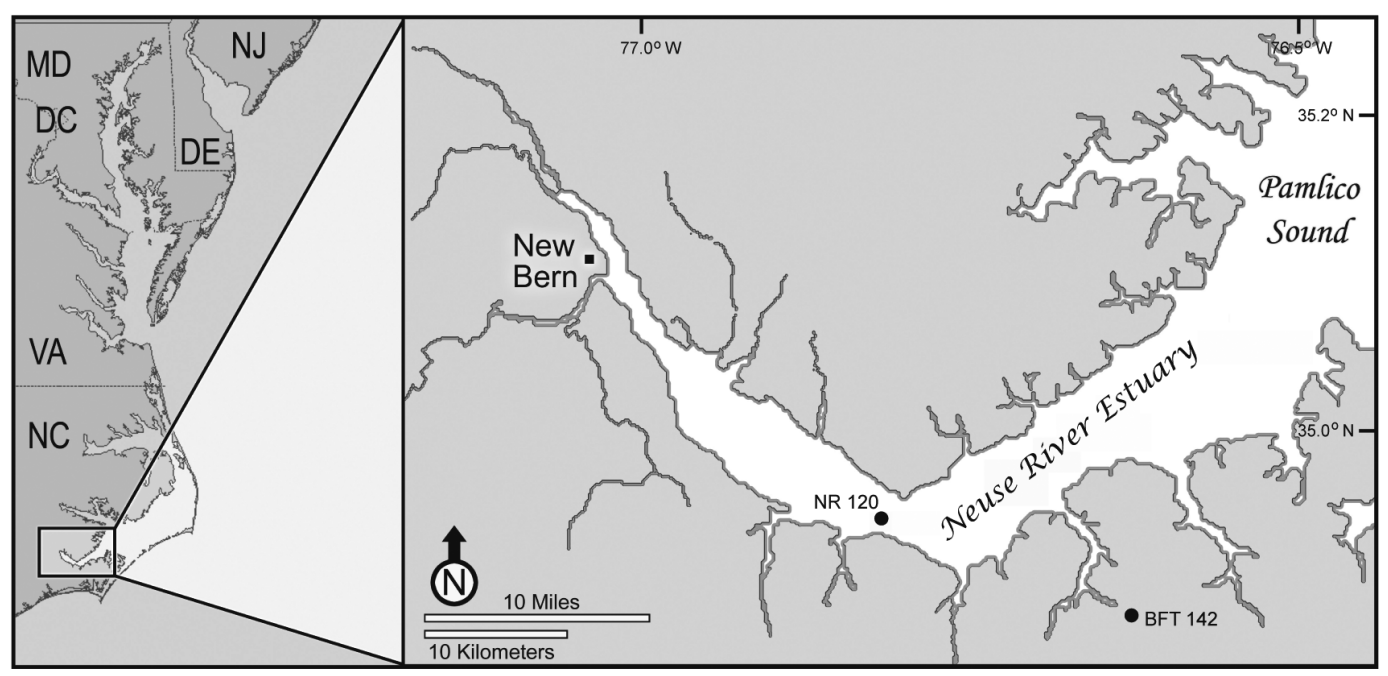

Fig. 1. The Neuse River Estuary, showing station NR 120-where the diel studies were performedand the meteorological station, BFT 142 
and fish kills (Mallin 1994, Hall et al. 2008). Given their ability to vertically migrate, understanding the relationships between flagellate depth distributions and vertical gradients of growth-limiting light and nutrient resources is crucial to understanding bloom dynamics and the resultant water quality within this system.

During 2 diel studies, we determined how the phytoplankton community was organized within the physical and chemical gradients of the NRE, with particular emphasis on growth-limiting light and nutrient resources. Results demonstrate that many of the dominant phytoflagellate species perform vertical migration behaviors in response to steep vertical separation of light and nutrient resources. Interspecific and intraspecific variation in migration patterns provide in situ evidence for striking flexibility in vertical migration responses of the flagellate community, which contributes to enhanced productivity within this eutrophic estuary.

\section{MATERIALS AND METHODS}

Two diel studies were performed in the NRE at station NR 120 (Fig. 1) on 12 to 13 June and 18 to 19 July 2001. Profiles of light, nutrients and phytoplankton biomass were made at 3 to $6 \mathrm{~h}$ intervals to identify diel patterns in the vertical distribution of phytoplankton and relate these patterns to water column structure. Because this study included vertical profiles of microscopically determined cell abundance, differences in patterns of phytoplankton distribution within taxonomic levels from class to species were discernable. Additionally, primary productivity and nutrient uptake studies were performed to investigate the linkage between patterns of resource availability and utilization.

Study site. The NRE is located along the midAtlantic seaboard of the USA (Fig. 1) and is a major tributary estuary of the Albemarle-Pamlico Sound estuarine system (Paerl et al. 1998, 2007, Peierls et al. 2003). The few narrow inlets in the Outer Banks of North Carolina restrict exchange with shelf waters and, as a result, astronomical tides in the NRE are negligible (Luettich et al. 2002). Riverine discharge and wind are the primary drivers of circulation, producing a partially mixed estuary where periods of strong salinity-based stratification are common (Luettich et al. 2000). Maximum depths along the axis of the estuary increase from $\sim 4 \mathrm{~m}$ at the head of the estuary to near $7 \mathrm{~m}$ where the estuary discharges to Pamlico Sound. Mean depth is only $2.3 \mathrm{~m}$ owing to extensive shelves and shoals that rim the estuary. The NRE has a multidecadal history of algal bloom and hypoxia problems associated with excessive anthropogenic nutrient loading (Paerl et al. 1998, 2004, 2007).
Station NR $120\left(34^{\circ} 57.132^{\prime}\right.$ N, $\left.76^{\circ} 48.779^{\prime} \mathrm{W}\right)$ is located near the bend in the estuary (Fig. 1), has a depth of $\sim 5.5 \mathrm{~m}$, and is mesohaline and mesotrophic to eutrophic (Boyer et al. 1994). Salinity is highly variable and largely dependent on riverine discharge (Christian et al. 1991). This site is monitored on a biweekly basis as part of the NRE Modeling and Monitoring (ModMon) Program (Luettich et al. 2000) that has collected environmental data within the NRE since 1994 (www. unc.edu/ims/neuse/modmon).

Sample collection. Water samples for determination of phytoplankton biomass, community composition, primary productivity and nutrient uptake were collected using a 21 Van Dorn sampler and immediately poured into 2 to 41 polyethylene bottles. Water was collected from $0.1,0.5,1,2,3.5$ and $5 \mathrm{~m}$ depths at roughly $3 \mathrm{~h}$ intervals. Time is reported as Eastern Standard Time.

Within minutes of collection, $150 \mathrm{ml}$ of each sample was poured into an amber polyethylene bottle and fixed with Lugol's solution at $1 \%$ final concentration for microscopic phytoplankton enumeration. Chlorophyll a ( $\mathrm{chl} \mathrm{a)} \mathrm{and} \mathrm{nutrient} \mathrm{measurements} \mathrm{were} \mathrm{made}$ at $0.5,2$ and $5 \mathrm{~m}$ for the early morning, noon, afternoon and midnight periods (roughly $6 \mathrm{~h}$ intervals). For chl a measurements, 3 aliquots of $50 \mathrm{ml}$ were filtered separately onto Whatman $25 \mathrm{~mm}$ GF/F filters (nominal poresize $0.7 \mu \mathrm{m}$ ). Filters were folded in half (content side faced inward), blotted with a paper towel to remove excess water, wrapped in aluminum foil and stored on ice in plastic bags for the duration of each $24 \mathrm{~h}$ observation (Paerl et al. 1995). The filtrate from the 3 filters was poured into acid-washed and sample-rinsed $150 \mathrm{ml}$ polyethylene bottles and stored on ice for the duration of each $24 \mathrm{~h}$ observation for subsequent analysis of dissolved nutrients. Once back at the laboratory, chl $a$ and nutrient samples were frozen at $-20^{\circ} \mathrm{C}$.

Physical data. Temperature, salinity and in vivo fluorescence profiles were collected coincidentally with each set of water samples using a YSI 6600 multiparameter water quality sonde. During the June diel study, measurements were made at $0.5 \mathrm{~m}$ depth intervals. In July, the YSI 6600 sonde continuously collected data at $1 \mathrm{~Hz}$ and produced a depth resolution of $\sim 0.1 \mathrm{~m}$. Profiles of photosynthetically active radiation (PAR) were collected before and after each productivity incubation using a Li-Cor 192S $4 \pi$ spherical PAR sensor. Diffuse attenuation coefficients $\left(K_{\mathrm{d}}\right)$ were calculated from least-squares fits of the exponential decay of PAR profiles. Hourly wind and incident solar radiation data were obtained from the US Environmental Protection Agency Clean Air Status and Trends Network site BFT $142\left(34^{\circ} 53.088^{\prime} \mathrm{N}, 76^{\circ} 37.218^{\prime} \mathrm{W}\right), 19 \mathrm{~km}$ east of NR 120 (Fig. 1) (www.epa.gov/castnet). Incident PAR ( $\mu \mathrm{mol}$ photons $\mathrm{m}^{-2} \mathrm{~s}^{-1}, 400-700 \mathrm{~nm}$ ) was approximated 
by multiplying incident solar radiation $\left(\mathrm{W} \mathrm{m}^{-2}, 400-\right.$ $1100 \mathrm{~nm}$ ) by 2.04 (Fisher et al. 2003). Wave height was estimated to the nearest $0.3 \mathrm{~m}$ (1 foot) at the time of each sampling.

Nutrient and chl a analyses. Frozen nutrient samples were quick-thawed and $\mathrm{NO}_{2}{ }^{-}+\mathrm{NO}_{3}{ }^{-}$(reported as $\mathrm{NO}_{3}{ }^{-}$), $\mathrm{NH}_{4}{ }^{+}$and $\mathrm{PO}_{4}{ }^{3-}$ concentrations were immediately determined using a Lachat Quick-chem 8000 auto-analyzer (Lachat Quik-chem methods 31-107-043-B, 31-107-04-1-C and 31-107-06-1-B, respectively). Detection limits for $\mathrm{NO}_{3}{ }^{-}, \mathrm{NH}_{4}{ }^{+}$and $\mathrm{PO}_{4}{ }^{3-}$ were 0.26 , 0.34 and $0.024 \mu \mathrm{M}$, respectively. Dissolved silica was not measured during this study because concentrations were always (597 of 597 biweekly measurements from station NR 120 since 1999) saturating for diatom growth in this region of the estuary $(>2 \mu \mathrm{M}$; Dortch \& Whitledge 1992). Chl a samples were analyzed within 1 wk of each diel observation and nutrient analyses were performed within 4 wk of each diel observation. For chl a analysis, filters were extracted using a tissue grinder in $90 \%$ acetone (EPA method 445.0; Arar et al. 1997). Chl a concentration of the extracts was measured using the non-acidification method of Welschmeyer (1994) on a Turner Designs TD-700 fluorometer calibrated with pure, liquid chl a standards.
Primary productivity and nitrogen uptake. Assays for primary productivity $\left({ }^{14} \mathrm{C}\right)$ and nitrogen $\left({ }^{15} \mathrm{~N}\right)$ uptake were timed to capture rates for the early morning, midday, afternoon and midnight periods with reported times indicating the beginning of each assay (Fig. 2). We focused on $\mathrm{N}$ uptake, rather than $\mathrm{N}$ and $\mathrm{P}$, because $\mathrm{N}$ has repeatedly been shown to be the limiting nutrient within the NRE during the summer (Rudek et al. 1991, Paerl et al. 1995, 2004).

For ${ }^{15} \mathrm{~N}$ uptake assays, whole-water samples from $0.5,2$ and $5 \mathrm{~m}$ depth were added to triplicate $150 \mathrm{ml}$ clear polyethylene terephthalate glycol bottles amended with trace concentrations $(0.1 \mu \mathrm{M})$ of ${ }^{15} \mathrm{~N}$ ammonium chloride $\left({ }^{15} \mathrm{NH}_{4} \mathrm{Cl}\right)$, potassium nitrate $\left(\mathrm{K}^{15} \mathrm{NO}_{3}\right)$ or urea $\left(\left({ }^{15} \mathrm{NH}_{2}\right)_{2} \mathrm{CO}\right)$ (Sigma Chemicals). For $\mathrm{NH}_{4}{ }^{+},{ }^{15} \mathrm{NH}_{4}{ }^{+}$represented a small portion of the total $\mathrm{NH}_{4}{ }^{+}$pool (range 1.4 to $18.7 \%$, mean $9.4 \%$ ); therefore, it seems unlikely that significant stimulation of $\mathrm{NH}_{4}{ }^{+}$uptake via increased substrate availability occurred. Calculation of in situ uptake of $\mathrm{NO}_{3}{ }^{-}$and urea was not possible because ambient concentrations were below analytical detection limits for 20 of $24 \mathrm{NO}_{3}{ }^{-}$samples and all 24 urea samples (see Twomey et al. 2005 for urea measurement methods). Samples were incubated in the water at the collection depth by suspending the bottles on a vertical line at 0.5,2 and $5 \mathrm{~m}$ depths. To prevent shading, the incubation line drifted
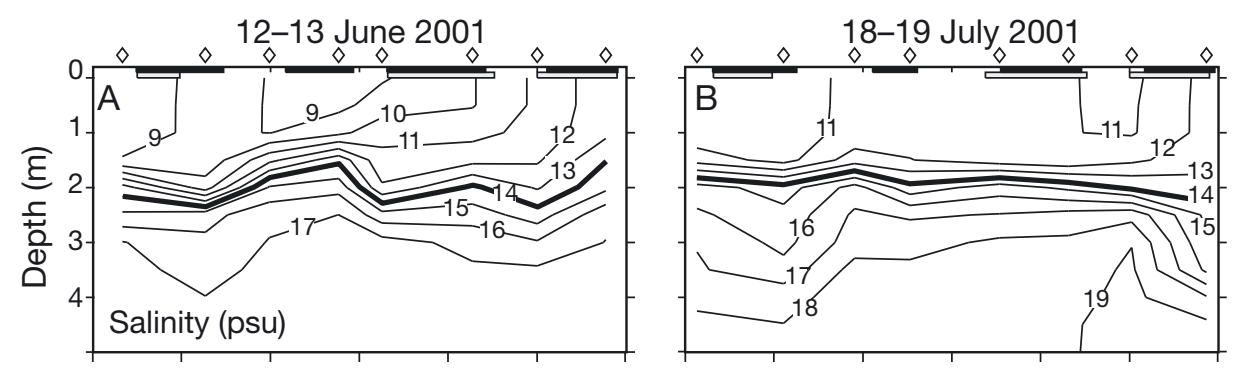
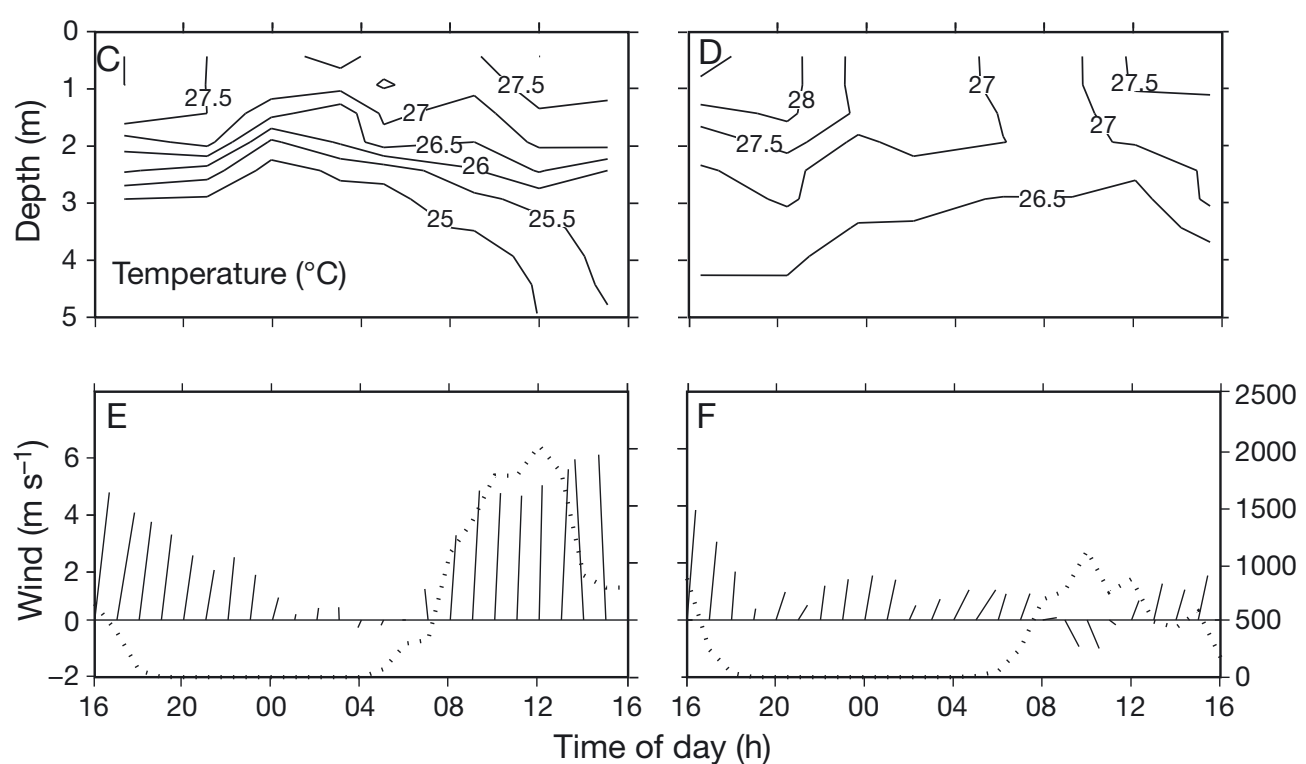

Fig. 2. $(\mathrm{A}, \mathrm{B})$ Salinity. Thick line indicates pycnocline depth represented by the $14 \mathrm{psu}$ isohaline. (C,D) Temperature profiles, and $(\mathrm{E}, \mathrm{F})$ hourly averaged wind vectors (solid lines) and hourly averaged incident solar radiation (dotted line) during the diel studies. Wind quivers point downwind, with up being north. Black bars, gray bars and open diamonds along the top of panels A and B represent incubation durations for $\mathrm{N}$ uptake and primary productivity assays, and timing of hydrographic profiles, respectively 
on a tether $\sim 5 \mathrm{~m}$ from the vessel. Incubations lasted from 2 to $5.1 \mathrm{~h}$ (Fig. 2) and were terminated by filtration onto pre-combusted $\left(500^{\circ} \mathrm{C}, 16 \mathrm{~h}\right)$ Whatman $25 \mathrm{~mm} \mathrm{GF} / \mathrm{F}$ filters (nominal pore-size $0.7 \mu \mathrm{m}$ ). While shipboard, filters were sealed in plastic Petri dishes and stored on ice. Immediately upon return to the Institute of Marine Sciences $\left(\sim 2 \mathrm{~h}\right.$ after the last assay), filters were dried at $60^{\circ} \mathrm{C}$. For ${ }^{15} \mathrm{~N}$ analysis and calculation of uptake rates, we used the procedures described by Twomey et al. (2005). Our ${ }^{15} \mathrm{NH}_{4}{ }^{+}$uptake method did not account for isotopic dilution caused by remineralization, which can lead to significant underestimation of true $\mathrm{NH}_{4}{ }^{+}$uptake rates (Glibert et al. 1982). All the $\mathrm{NH}_{4}{ }^{+}$uptake rates reported in the present study are, therefore, considered minimum uptake rates. We used the minimum $\mathrm{NH}_{4}{ }^{+}$uptake rates to calculate a maximum turnover time for the ambient $\mathrm{NH}_{4}{ }^{+}$pool in the water column by dividing the ambient $\mathrm{NH}_{4}{ }^{+}$concentration by the minimum uptake rate.

Primary productivity was determined using the ${ }^{14} \mathrm{C}$ method adapted for in situ estuarine conditions by Paerl (1987). Triplicate light and single dark $150 \mathrm{ml}$ polyethylene terephthalate glycol bottles were filled with water collected from $0.5,2$ and $5 \mathrm{~m}$ depths followed by the addition of $0.3 \mathrm{ml}$ of a ${ }^{14} \mathrm{C} \mathrm{NaHCO}_{3}$ solution with an activity of $7.5 \mu \mathrm{Ci} \mathrm{ml}^{-1}$, (58 $\mathrm{mCi} \mathrm{mmol}^{-1}$ specific activity, ICN Pharmaceuticals). Incubations were conducted at the sampling depth, in the same manner as the ${ }^{15} \mathrm{~N}$ incubations. After a $\sim 3 \mathrm{~h}$ incubation period (Fig. 2), $50 \mathrm{ml}$ aliquots from each bottle were filtered onto Whatman $25 \mathrm{~mm} \mathrm{GF/F} \mathrm{filters.} \mathrm{Filters} \mathrm{were}$ then sealed in plastic Petri dishes and stored on ice. Immediately upon return to the Institute of Marine Sciences, filters were fumed with $\mathrm{HCl}$ to remove inorganic ${ }^{14} \mathrm{C}$ and air dried. ${ }^{14} \mathrm{C}$ incorporation was measured using a Beckman TD-5000 liquid scintillation spectrometer. Dissolved inorganic $\mathrm{C}$ was determined by acidification and measurement of the evolved $\mathrm{CO}_{2}$ gas with a Beckman 865 infrared gas analyzer (Paerl 1987). Primary productivity was calculated according to the formula of Wetzel \& Likens (1991).

To understand how vertical distributions of phytoplankton impacted productivity, we first characterized the light dependence of photosynthesis from both days by comparing the observed chl a specific productivity $\left(P^{\mathrm{B}}\right)$ with PAR flux for each time point and all 3 depths. Phytoplankton layering can cause light to attenuate unevenly in the water column and may produce errors in estimating PAR flux at a specific depth based on incident PAR and $K_{\mathrm{d}}$ (Wetzel 2001). Therefore, PAR flux during the incubations was estimated as the mean of the actual PAR measurements at each sampling depth made at the beginning and end of each incubation. Afternoon productivity incubations were terminated at sunset (Fig. 2). Because there was essentially no incident PAR to the water at sunset, PAR profiles were not made and PAR was assumed to be zero at all depths. We empirically modeled the observed relationship between $P^{\mathrm{B}}$ and PAR using a least-squares fit to a hyperbolic tangent model (Jassby \& Platt 1976). Using this empirical model, we calculated the productivity expected if chl a was evenly distributed throughout the water column. For each productivity measurement, we assumed that chl $a$ at each depth equaled the mean chl a from 0.5, 2 and $5 \mathrm{~m}$ sampling depths. We then multiplied these mean chl a values by the modeled $P^{\mathrm{B}}$ for the given PAR flux to obtain a modeled productivity value and compared these values with the observed productivities. Productivity values were integrated by depth and time using trapezoidal integration (see Hall et al. 2008 for details) to provide areal $\left(\mathrm{m}^{-2}\right)$ estimates of productivity for each incubation and for the entire photoperiod. For integration over the photoperiod, afternoon productivity values were reordered so that the afternoon values followed the morning and midday measurements, although the measurements were actually made the previous day (see Fig. 2).

Phytoplankton enumeration. Cell counts were performed using the inverted microscope technique of Utermöhl (1958) with a Thomas Scientific microscope under phase contrast at a magnification of $400 \times$. Smaller phytoplankton were likely underrepresented in the counts because the $24 \mathrm{~h}$ settling time was not sufficient to ensure that all of the nano- and picophytoplankton had settled (Hall 2009). However, consistent settling time and use of the same size settling chamber throughout the study $(30.8 \mathrm{ml}, 10 \mathrm{~cm}$ height) provided a sufficient basis for comparing samples. For each sample, 65 to 255 fields were counted, providing between 34 and 1973 counts of the most abundant of 15 to 27 cell types. We were unable to identify some cell types to the genus level. For example, small (generally 4 to $5 \mu \mathrm{m}$ diameter), solitary centric diatoms were grouped and not identified further. Drawings and/or photomicrographs of each common phytoplankton species were made to record cell sizes for estimation of biovolumes from published sources.

Analysis of phytoplankton depth profiles. Both horizontal and vertical advection of phytoplankton patches can produce changes in depth patterns that may be mistaken for active vertical migration patterns (HappeyWood 1976, Denman 1977). Our analyses define the statistical significance of DVM patterns and also address the likelihood of advection of phytoplankton patches producing apparent DVM patterns; issues commonly not addressed in descriptions of vertical migration behaviors (Jones 1988).

The center of mass of the phytoplankton depth distribution for each profile $\left(Z_{\text {cent }}\right)$ was used as a metric to describe changes in the depth distribution in a manner that was independent of the absolute concentrations 
between profiles (Denman 1977). $Z_{\text {cent }}$ was calculated for the common species, classes and in vivo fluorescence as:

$$
Z_{\text {cent }}=\sum_{z=0}^{z=H} C_{z} \times z / \sum_{z=0}^{z=H} C_{z}
$$

where $z$ is the sampling depth of each biomass value, $C_{z}$ is the biomass value at depth $z$ and $H$ is water column depth.

In stratified waters, vertical advection of phytoplankton patches via the propagation of internal waves along the pycnocline is common and can be mistaken for active vertical migration, particularly if the wave period is close to $24 \mathrm{~h}$ (Denman 1977). By subtracting $Z_{\text {cent }}$ from the depth of the pycnocline, erroneously perceived changes in vertical distribution brought about by changes in the depth of the pycnocline were avoided. Pycnocline depth for each profile was defined as the depth of the 14 psu isohaline, which was consistently found in the region where the maximum density gradient occurred (Fig. 2). To assess the statistical significance of observed diel changes in phytoplankton depth distributions, time series of $Z_{\text {cent }}$ were correlated with a cosine wave with a midday maximum and midnight minimum. A significant DVM pattern was defined by a significant positive correlation $(\alpha<$ $0.05)$ between the observed diel change in $Z_{\text {cent }}$ and the cosine wave.

Short-term changes in the vertical profiles of immotile cells indicate water movement, which should redistribute all phytoplankton unless they are capable of effectively swimming against mixing (HappeyWood 1976). Redistribution of flagellates due to mixing is accounted for by comparing observed patterns of phytoflagellate vertical distribution against the vertical distributions of the most common non-motile phytoplankton groups.

The possibility that random horizontal advection coupled with horizontal patchiness of phytoplankton could produce an apparent DVM pattern solely by chance was addressed by comparing the variability with depth against the variability with time using a 2-way ANOVA of depth, time and their interaction against total cell abundances of the dominant 3 phytoplankton classes during each diel study. A significant time effect would indicate that advection of phytoplankton patches are a potentially important factor in determining phytoplankton biomass within the profiles (Happey-Wood 1976). Both depth and time were treated as categorical variables and were grouped into 4 time and 3 depth categories. Time was divided into night $(20: 00$ to $02: 00 \mathrm{~h})$, morning $(02: 00$ to $08: 00 \mathrm{~h})$, midday (08:00 to $14: 00 \mathrm{~h})$ and afternoon (14:00 to 20:00 h). Depth was divided into near-surface (0.1 and $0.5 \mathrm{~m})$, mid-depth (1 and $2 \mathrm{~m}$ ) and below pycnocline
( 3.5 and $5 \mathrm{~m}$ ) categories. This design resulted in a $4 \times 3$ matrix of cells with each cell containing 4 phytoplankton class abundance values. Transformation of the cell abundance data $(c)$ by $\log (c+1)$ resulted in the data conforming to the assumption of normality and homogeneity of variance as tested by Lilliefors' and Bartlett's tests, respectively.

\section{RESULTS}

\section{Hydrographic and weather conditions}

Throughout both diel studies, the water column was stratified with salinity and temperature differences of 4 to $8 \mathrm{psu}$ and 2 to $3^{\circ} \mathrm{C}$ from the surface to the bottom of the $\sim 5.5 \mathrm{~m}$ deep water column (Fig. 2A-D). Salinity was responsible for $>93 \%$ of vertical density variation (calculated according to Gowen et al. 1995) and therefore is a suitable proxy for density. Salinity and temperature increased from June to July, with mean water column salinities of $\sim 12$ and $\sim 15 \mathrm{psu}$ and mean water column temperatures of $\sim 26$ and $\sim 27^{\circ} \mathrm{C}$, respectively (Fig. 2A-D). During both diel studies, the upper mixed layer was $\sim 1.5 \mathrm{~m}$ thick and was separated from the bottom waters by the pycnocline $(\sim 1.5$ to $3 \mathrm{~m})$ centered at $\sim 2 \mathrm{~m}$ depth (Fig. 2A,B) with a salinity of $14 \mathrm{psu}$.

A pronounced diel sea breeze pattern was evident during June with south winds reaching $6 \mathrm{~m} \mathrm{~s}^{-1}$ in the late afternoon and very light to windless conditions during the nighttime and early morning (Fig. 2E). In July, winds were generally south-southwest and only exceeded $2 \mathrm{~m} \mathrm{~s}^{-1}$ during the late afternoon of 18 July (Fig. 2F). Wave heights were $<0.3 \mathrm{~m}$ except during the afternoon of 13 June, when wind speed increased to $\sim 6 \mathrm{~m} \mathrm{~s}^{-1}$ and wave height increased briefly to $\sim 0.6 \mathrm{~m}$. Clear skies in June allowed incident irradiance to reach $\sim 2000 \mu \mathrm{mol}$ photons $\mathrm{m}^{-2} \mathrm{~s}^{-1}$ at midday and irradiance was only slightly suppressed during early afternoon (Fig. 2E). In contrast, dense cloud cover approximately halved incident irradiance on 19 July (Fig. 2F).

\section{Nutrients and dissolved inorganic nitrogen uptake}

Dissolved inorganic nitrogen (DIN) was principally in the form of $\mathrm{NH}_{4}{ }^{+}$throughout both diel studies. $\mathrm{NO}_{3}{ }^{-}$ was below detection for all samples during June. In July, 4 samples collected from 0.5 and $2 \mathrm{~m}$ depth contained low $(<0.5 \mu \mathrm{M})$ but measurable $\mathrm{NO}_{3}{ }^{-}$. $\mathrm{NH}_{4}{ }^{+}$in the surface waters $(0.5 \mathrm{~m})$ generally ranged from $\sim 0.5$ to $\sim 1 \mu \mathrm{M}$ for both diel studies (Table 1 ). $\mathrm{NH}_{4}{ }^{+}$concentrations at $2 \mathrm{~m}$, near the pycnocline, closely matched those at the surface for each profile. During the June diel study, bottom-water $\mathrm{NH}_{4}{ }^{+}$was consistently 4 to 7 
Table 1. $\mathrm{NH}_{4}{ }^{+}$and $\mathrm{PO}_{4}{ }^{3-}$ concentrations, minimum $\mathrm{NH}_{4}{ }^{+}$uptake rates and maximum turnover times for the $\mathrm{NH}_{4}{ }^{+}$pool in the Neuse River Estuary, North Carolina, USA. Values are means \pm SD from near-surface, near-pycnocline and subpycnocline depths

\begin{tabular}{|lccccc|}
\hline Date & $\begin{array}{c}\text { Depth } \\
(\mathrm{m})\end{array}$ & $\begin{array}{c}{\left[\mathrm{PO}_{4}{ }^{3-}\right]} \\
(\mu \mathrm{M})\end{array}$ & $\begin{array}{c}{\left[\mathrm{NH}_{4}{ }^{+}\right]} \\
(\mu \mathrm{M})\end{array}$ & $\begin{array}{c}\mathrm{NH}_{4}{ }^{+} \text {Uptake } \\
\left(\mu \mathrm{M} \mathrm{h}{ }^{-1}\right)\end{array}$ & $\begin{array}{c}\mathrm{NH}_{4}{ }^{+} \text {Turn- } \\
\text { over }(\mathrm{h})\end{array}$ \\
\hline 12-13 June 2001 & 0.5 & $0.34 \pm 0.084$ & $0.78 \pm 0.15$ & $0.22 \pm 0.073$ & $3.71 \pm 0.64$ \\
& 2 & $0.53 \pm 0.26$ & $0.89 \pm 0.25$ & $0.21 \pm 0.081$ & $4.36 \pm 0.70$ \\
& 5 & $1.29 \pm 0.10$ & $5.75 \pm 1.49$ & $0.091 \pm 0.025$ & $69.9 \pm 37.1$ \\
18-19 July 2001 & 0.5 & $0.85 \pm 0.077$ & $1.10 \pm 0.27$ & $0.28 \pm 0.070$ & $4.07 \pm 0.91$ \\
& 2 & $0.98 \pm 0.067$ & $1.09 \pm 0.56$ & $0.27 \pm 0.12$ & $4.13 \pm 1.01$ \\
& 5 & $2.48 \pm 0.39$ & $1.79 \pm 0.46$ & $0.16 \pm 0.090$ & $15.3 \pm 11.1$ \\
\hline
\end{tabular}

availability in July and a consistent $P^{\mathrm{B}}$ versus PAR relationship, midday primary productivity was very similar between June and July with

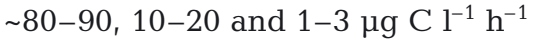
measured at the $0.5,2$ and $5 \mathrm{~m}$ depths, respectively, for both diel studies (Fig. 3C). This was due to the high near-surface biomass ( 40 $\mathrm{\mu g}$ chl $a^{-1}$ ) on 19 July (Fig. 3B), which increased near-surface $(0.5 \mathrm{~m})$ productivity by $\sim 85 \%$ (Fig. 4B) and increased the depth integrated productivity by $>100 \%$ over what would

times higher than at the surface or near pycnocline depths. In July, bottom-water $\mathrm{NH}_{4}{ }^{+}$was 1.2 to 3 times higher than near the surface. Surface-water $\mathrm{PO}_{4}{ }^{3-}$ ranged from 0.25 to $0.8 \mu \mathrm{M}$ and bottom-water $\mathrm{PO}_{4}{ }^{3-}$ $(1.2$ to $>3 \mu \mathrm{M})$ was always higher than at the surface. DIN to dissolved inorganic phosphorus molar ratios were much lower than Redfield ratios (Redfield 1958), ranging from 0.55 to 5.56 with a mean $( \pm \mathrm{SD})$ of $2.00 \pm 1.35$.

For near-surface $(0.5 \mathrm{~m})$ and near-pycnocline $(2 \mathrm{~m})$ waters, the maximum turnover time of $\mathrm{NH}_{4}{ }^{+}$was $\sim 4 \mathrm{~h}$ (Table 1). Maximum turnover times were much longer for the bottom waters than for the near-surface waters ( $\sim 15 \mathrm{~h}$ in June and $\sim 70 \mathrm{~h}$ in July) owing to generally lower minimum uptake rates and the much larger pool of $\mathrm{NH}_{4}^{+}$(Table 1).

\section{Light and primary productivity}

Attenuation of PAR within and between the 2 diel studies (Fig. 3A) was very similar. Midday values of the diffuse PAR attenuation coefficient for June and July were 1.28 and $1.39 \mathrm{~m}^{-1}$, respectively, and standard deviations for the complete set of PAR profiles $(n=5)$ from both diel studies (data not shown) were less than $0.1 \mathrm{~m}^{-1}$. During both diel studies, light at the center of the pycnocline $(\sim 2 \mathrm{~m})$ was consistently 6 to $8 \%$ and light in the bottom waters $(>3.5 \mathrm{~m})$ was $<1 \%$ incident irradiance (Fig. 3A). However, because of differences in cloud cover (Fig. 2E,F), light availability in June was more than twice that in July (Fig. 3A).

During both diel studies, productivity normalized to chl a $\left(P^{\mathrm{B}}\right)$ closely tracked PAR availability, as shown for the midday $P^{\mathrm{B}}$ profiles (Fig. 3D) and for the comparison of all $P^{\mathrm{B}}$ measurements against PAR (Fig. 4A). The hyperbolic tangent model fit the observed relationship between $P^{\mathrm{B}}$ and PAR well $\left(\mathrm{R}^{2}=0.92\right)$. However, PAR was never fully saturating, which can lead to errors in estimation of $P^{\mathrm{B}}{ }_{\text {max }}$ (MacIntyre et al. 2002). We will address the likelihood and potential implications of inaccurately estimating $P^{\mathrm{B}}{ }_{\max }$ in the 'Discussion'. Despite lower PAR be expected for a vertically homogenous phytoplankton community (Table 2). In fact, for all productivity profiles except during the afternoon of 18 July, the observed vertical heterogeneity of chl a increased depth integrated productivity (Table 2). On a daily basis, the observed productivity was $15 \%$ higher in June but $113 \%$ higher in July than would have been expected for evenly distributed chl a (Table 2).
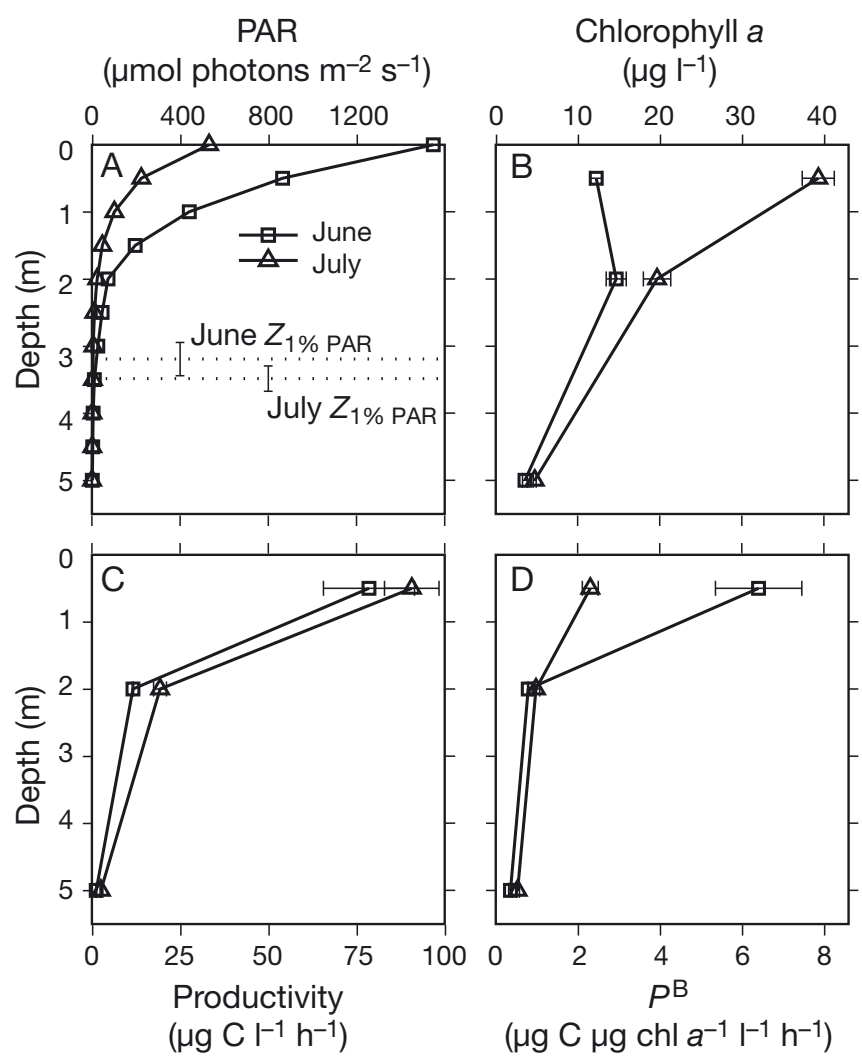

Fig. 3. (A) Midday depth profiles of photosynthetically active radiation (PAR), (B) chlorophyll $a_{1}(\mathrm{C})$ primary productivity and (D) biomass (chlorophyll a)-specific primary productivity $\left(P^{\mathrm{B}}\right)$. Dotted horizontal lines in A represent the mean depth of the euphotic zone ( $1 \%$ incident PAR) from the 5 measured PAR profiles during each diel study. Error bars represent standard deviations 

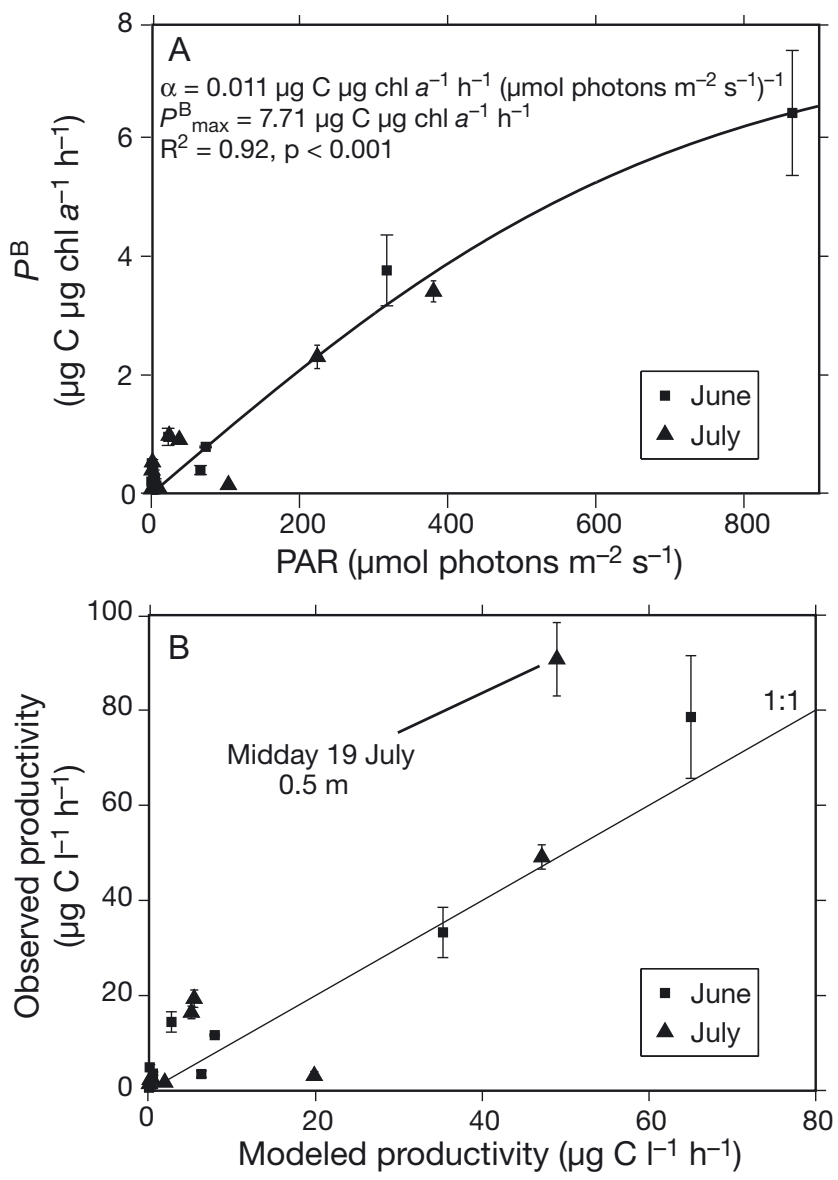

Fig. 4. Scatter plots of (A) photosynthetically active radiation (PAR) vs. biomass (chlorophyll a)-specific primary productivity $\left(P^{\mathrm{B}}\right)$ and $(\mathrm{B})$ observed versus modeled primary productivity, which assumes a vertically homogenous chlorophyll a distribution. Data come from all 3 depths $(0.5,2$ and $5 \mathrm{~m})$ for the morning, midday and afternoon productivity assays conducted during the June and July diel studies. Solid line in A represents the best fit to the hyperbolic tangent model (Jassby \& Platt 1976). Solid line in B represents the 1:1 ratio between observed and modeled primary production

\section{Vertical distribution of the phytoplankton in June}

The 6 most abundant phytoplankton species or groups (Fig. 5) constituted $88 \%$ of total phytoplankton cell abundance. The community was dominated by flagellates, and the dinoflagellates cf. Karlodinium veneficum and Scrippsiella trochoidea, the cryptophyte Cryptomonas sp. and the euglenophyte Eutreptia sp. all displayed statistically significant DVM patterns (Fig. 6). The nanoplanktonic cryptophyte cf. Chroomonas minuta (Campbell 1973) and the dinoflagellate Prorocentrum minimum generally displayed maximum abundance at depths close to or above the pycnocline (Fig. 5I-P, OO-VV), with no statistically significant DVM pattern (Fig. 6).
Table 2. Morning, midday, afternoon and integrated daily values of observed depth-integrated primary productivity (subperiods: $\mathrm{mg} \mathrm{C} \mathrm{m} \mathrm{Ch}^{-2} \mathrm{~h}^{-1}$, whole day: $\mathrm{g} \mathrm{C} \mathrm{m}^{-2} \mathrm{~d}^{-1}$ ) in the Neuse River Estuary and modeled depth-integrated primary productivity that assumes a vertically homogenous chlorophyll a distribution. Afternoon productivity measurements were made prior to the morning and midday measurements on the previous day (see Fig. 2)

\begin{tabular}{|lcc|}
\hline \multirow{2}{*}{ Date } & \multicolumn{2}{c|}{ Primary productivity } \\
Time period & Observed & Modeled \\
\hline 12-13 June 2001 & & \\
Morning & 57.0 & 49.8 \\
Midday & 120.0 & 98.1 \\
Afternoon & 10.3 & 8.9 \\
Whole day & 1.73 & 1.51 \\
18-19 July 2001 & & \\
Morning & 90.2 & 69.9 \\
Midday & 147.9 & 72.1 \\
Afternoon & 2.8 & 28.9 \\
Whole day & 3.24 & 1.52 \\
\hline
\end{tabular}

Highest cell abundances of cf. Karlodinium veneficum were nearly always observed in the pycnocline region, but abundances above the pycnocline were higher during the daytime (Fig. 5Q-X). High concentrations of cf. $K$. veneficum were never found below the pycnocline at the 3.5 and $5 \mathrm{~m}$ depths (Fig. 5Q-X). In contrast, Scrippsiella trochoidea displayed maximum abundances below the pycnocline at $3.5 \mathrm{~m}$ at night, though very few cells were found deeper (Fig. 5Z,AA). During the early morning, $S$. trochoidea maxima were found near the pycnocline, with a large portion of cells remaining below the pycnocline (Fig. 5BB, CC). By mid-morning, a distinct population maximum of both $S$. trochoidea and cf. Gymnodinium danicans formed at $1 \mathrm{~m}$ depth but deepened by midday to $2 \mathrm{~m}$, only to migrate again to shallower depths by mid-afternoon (Fig. 5DD-FF, LL-NN). Maximum concentrations of the dinoflagellate cf. G. danicans were generally found near or just above the pycnocline at concentrations of 40 to 100 cells ml$^{-1}$ (Fig. 5GG-NN). Early in the morning (Fig. 5JJ, KK), dense patches of cf. G. danicans $\left(\sim 1000\right.$ cells $\left.\mathrm{ml}^{-1}\right)$ were observed at 1 to $2 \mathrm{~m}$ depths but, nearer midnight (Fig. 5HH,II), these patches appeared to be virtually absent from the water column. The non-motile phytoplankton, small centric diatoms (Fig. 5WW-DDD) and the chlorophyte Ankistrodesmus sp. did not display DVM patterns but generally had higher abundances at or above the pycnocline, as indicated by generally positive $Z_{\text {cent }}$ values (Fig. 6).

Because of their abundance and large size, dinoflagellates constituted a large proportion of the phytoplankton biomass and this was reflected in the in vivo 


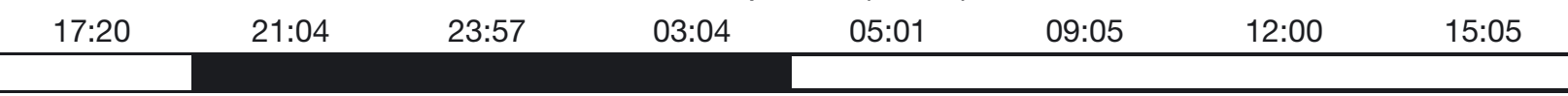

\section{- - Salinity (psu)}

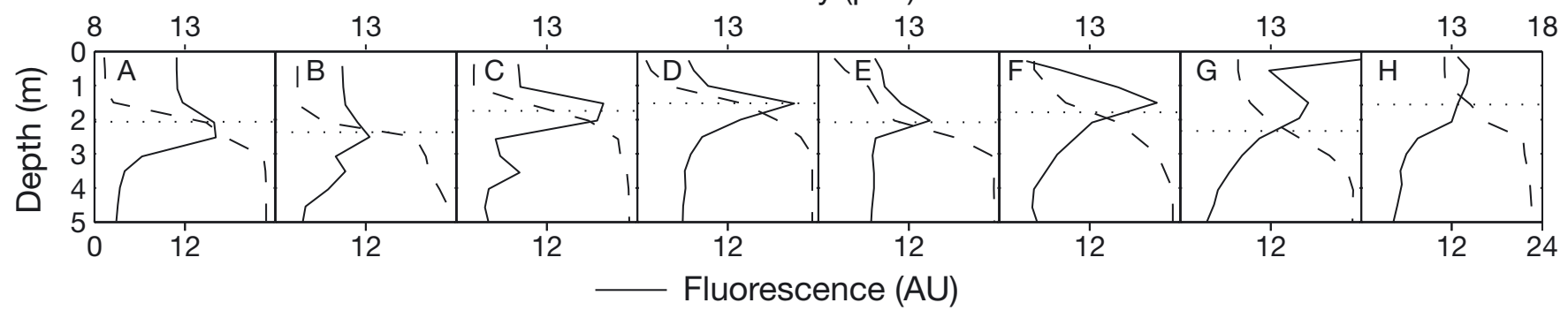

Cell abundance (cells ml-1)

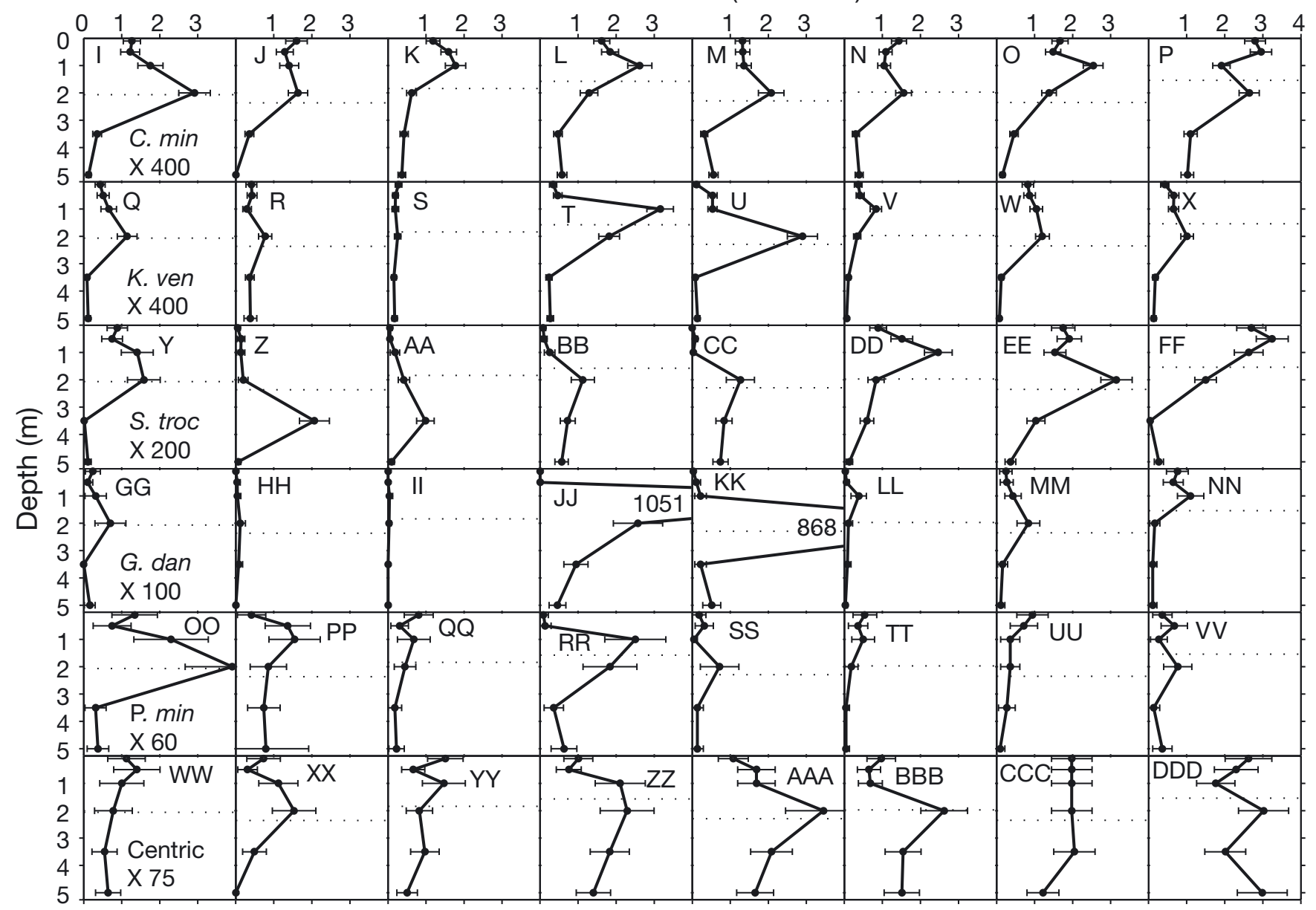

Fig. 5. Vertical distribution of (A-H) in vivo fluorescence and salinity and (I-DDD) cell abundances of the top 6 numerically dominant phytoplankton species or groups during the 12-13 June 2001 diel study. Light/dark bar along top indicates whether profile was collected during daytime or nighttime. In top panels, in vivo fluorescence, salinity and pycnocline depth are represented by solid, dashed and dotted horizontal lines, respectively. Species abbreviations are as follows: C. min = cf. Chroomonas minuta, $K$. ven $=$ cf. Karlodinium veneficum, $S$. troc $=$ Scrippsiella trochoidea, G. dan $=$ cf. Gymnodinium danicans, P. min = Prorocentrum minimum and Centric $=$ small $(<20 \mu \mathrm{m}$ diameter $)$ centric diatoms. Multiplication of the scale factors (below species abbreviations) by the abscissa yields cell abundance. Cell abundances higher than figure limits are displayed without scaling. Error bars represent the $90 \%$ confidence intervals for the abundance estimates 


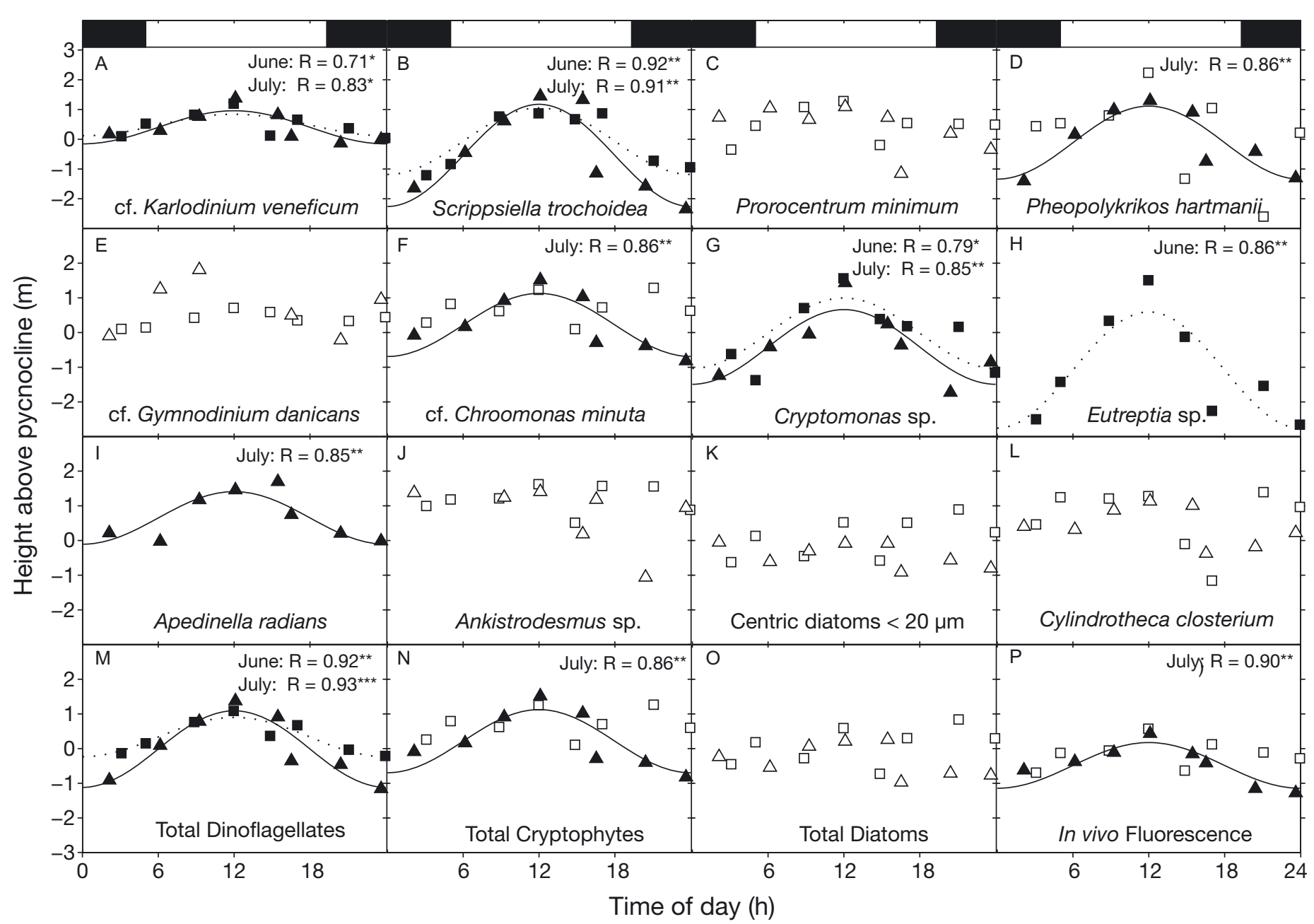

Fig. 6. Diel patterns in the center of mass for the (A-L) common phytoplankton species, (M-O) classes and (P) in vivo fluorescence of the phytoplankton community during the June (squares) and July (triangles) diel studies. Filled symbols indicate a statistically significant diel cycle based on the Pearson's correlation (r-values) between the center of mass with respect to the pycnocline and a cosine wave with zero phase shift (dotted line for June, solid line for July). ${ }^{*} \mathrm{p}<0.05_{i}{ }^{* *} \mathrm{p}<0.01 ;{ }^{* * *} \mathrm{p}<0.001$

fluorescence profiles. For example, nocturnal fluorescence peaks below the pycnocline at $3.5 \mathrm{~m}$ (Fig. 5B,C) were most likely due to Scrippsiella trochoidea, and the unusually high near-surface fluorescence during the noon profile (Fig. 5G) coincided with high concentrations (350 cells $\mathrm{ml}^{-1}$ ) of the large dinoflagellate Pheopolykrikos hartmanii (data not shown).

\section{Vertical distribution of the phytoplankton in July}

The 6 most abundant phytoplankton species or groups (Fig. 7) constituted 92\% of total phytoplankton cells. As in June, the community was dominated by flagellates, and the dinoflagellates cf. Karlodinium veneficum, Scrippsiella trochoidea and Pheopolykrikos hartmanii, the cryptophytes cf. Chroomonas minuta and Cryptomonas sp. and the chrysophyte Apedinella radians all displayed significant DVM patterns (Fig. 6). Growth conditions were poor relative to June because of low incident PAR and lower bottom-water nutrient concentrations (Fig. 2, Table 1). Coincident with these conditions, the observed DVM patterns were generally more exaggerated, with cells ascending higher during the day and deeper into the water column at night. The higher ascent of cells at midday was responsible for the high midday primary productivity during July.

The DVM pattern of cf. Chroomonas minuta resulted in the highest cell concentrations: $>5000$ cells $\mathrm{ml}^{-1}$ at $3.5 \mathrm{~m}$ at night (Fig. $7 \mathrm{~K}$ ) and $>10000$ cells ml $^{-1}$ at $0.5 \mathrm{~m}$ at midday (Fig. 7O). Apedinella radians and cf. Karlodinium veneficum exhibited very similar DVM patterns (Fig. 7 Q-FF). Early in the night (Fig. 7R,Z), a sizeable fraction of the populations were found below the pycnocline whereas later in the night and through the early morning (Fig. 7S-U, AA-CC) the vast major- 

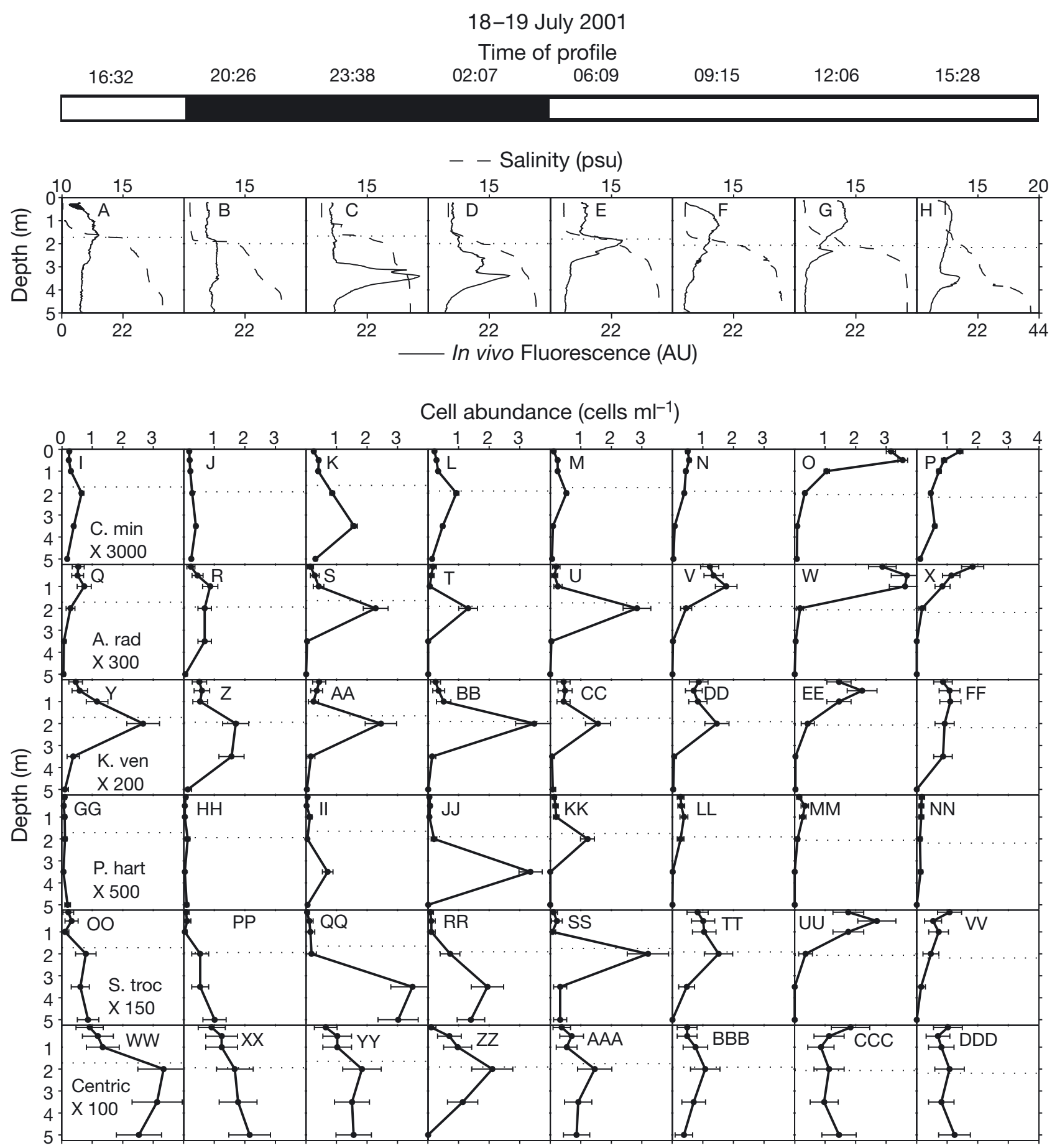

Fig. 7. Vertical distribution of (A-H) in vivo fluorescence and salinity and (I-DDD) cell abundances of the top 6 numerically dominant phytoplankton species or groups during the 18-19 July 2001 diel study. Figure configuration is identical to Fig. 5. Species abbreviations are as follows: $C$. $\min =$ cf. Chroomonas minuta, A. rad=Apedinella radians, $K$. ven = cf. Karlodinium veneficum, $P$. hart $=$ Pheopolykrikos hartmanii, $S$. troc $=$ Scrippsiella trochoidea, Centric $=$ small $(<20 \mu m$ diameter $)$ centric diatoms

ity of cells of both species occurred along the pycnocline. By midmorning (Fig. 7V, DD), cells from the pycnocline started to accumulate in the surface waters. By midday (Fig. 7W, EE), the majority of cells of both species were in the upper $1 \mathrm{~m}$ and were accompanied by cell abundance maxima of Scrippsiella trochoidea (Fig. 7UU) and Pheopolykrikos hartmannii (Fig. 7MM). Compared with June, both cf. K. veneficum and S. trochoidea moved higher into the water column during midday (Fig. 5W, EE, 7EE, UU). For cf. K. veneficum, 
a larger portion of cells were found below the pycnocline at night in July (Fig. 5R,S, 7Z) and S. trochoidea showed evidence of deeper nocturnal migration compared with that in June, with high concentrations of cells at both 3.5 and $5 \mathrm{~m}$ (Fig. 5Z, AA, Fig. 7PP-RR). During the day, maximum cell concentrations of Pheopolykrikos hartmanii were found at or above the pycnocline (Fig. 7KK-NN) and at night, dense aggregations (>1600 cells ml ${ }^{-1}$ ) occurred below the pycnocline $(3.5 \mathrm{~m})$ (Fig. 7II, JJ). As in June, the other common dinoflagellates, Prorocentrum minimum and cf. Gymnodinium danicans, and the non-motile groups, the chlorophyte Ankistrodesmus sp., the common pennate diatom $C_{Y}$ lindrotheca closterium and the small centric diatoms did not display significant DVM patterns (Fig. 6).

In vivo fluorescence profiles, as in June, generally tracked the vertical distribution of the large dinoflagellates such as Scrippsiella trochoidea and Pheopolykrikos hartmanii (Fig. 7A-H). In July, the resulting DVM pattern of in vivo fluorescence was statistically significant (Fig. 6). We speculate that decimeter-scale structure within the nocturnal fluorescence peak from 2.5 to $4 \mathrm{~m}$ (Fig. 7C,D) was due to different flagellate species, but our sampling resolution precluded this determination.

\section{Effects of horizontal advection}

ANOVA results for total dinoflagellates in June and both total dinoflagellate and cryptophyte abundance in July showed significant depth effects and significant interactions between depth and time (Table 3). Comparing the mean cell abundances for each depth level (data not shown) demonstrated that the significant depth effect was due to the general trend toward higher abundance at mid-depths, as can be seen in Figs. $5 \& 7$. The significant interaction indicates that abundance at a given depth level was dependent on the time of day, an outcome determined through the statistically significant DVM cycles of the dinoflagellates and cryptophytes (Fig. 6). Horizontal advection of phytoplankton patches is unlikely to have produced the observed DVM patterns because time was not a significant predictor of abundance.

Although it is impossible to prove with certainty that apparent DVM patterns were truly a result of DVM, the following results, in combination, provide strong evidence to support DVM as the cause of the observed diel vertical distribution patterns: (1) ANOVA results indicate that horizontal advection was an unlikely cause of DVM patterns; (2) the DVM patterns of flagellates were repeated during both studies, although with slight differences; (3) changes in pycnocline depth did not affect apparent DVM patterns of $Z_{\text {centi }}$ and (4) there was a lack of apparent DVM patterns from the common non-flagellate phytoplankton.

\section{Relationship between cell size and DVM amplitude}

We compared the equivalent spherical diameter and the amplitude of the best-fit cosine wave for $Z_{\text {cent }}$ for each flagellate species that displayed a statistically significant DVM pattern. A Spearman's rank correlation showed a significant trend of higher DVM amplitude with increasing cell size (Fig. 8). Even if the mean DVM amplitude for each species was used (with a reduction of $\mathrm{n}$ from 10 to 7), the relationship between size and DVM amplitude was still significant ( $p=0.032)$. The smaller flagellates-cf. Karlodinium veneficum, cf. Chroomonas minuta and Apedinella radians-had DVM amplitudes of $<1 \mathrm{~m}$ whereas the larger microplankton-Scrippsiella trochoidea, Cryptomonas sp., Eutreptia sp. and Pheopolykrikos hartmanii-had DVM amplitudes of $>1 \mathrm{~m}$. DVM amplitudes were higher in July than June for the 3 species that displayed statistically significant DVM patterns on both days.

\section{DISCUSSION}

\section{DVM and the vertical separation of light and nutrients}

Through DVM, flagellates are able to temporally and spatially separate photosynthesis and nutrient uptake (Fraga et al. 1992), and thus efficiently exploit vertically separated light and nutrient resources on daily time scales relevant to the growth of individual cells. At the concentrations of DIN observed in the surface waters during the present study $(\sim 1 \mu \mathrm{M})$, phytoplankton assemblages from the NRE showed considerable 


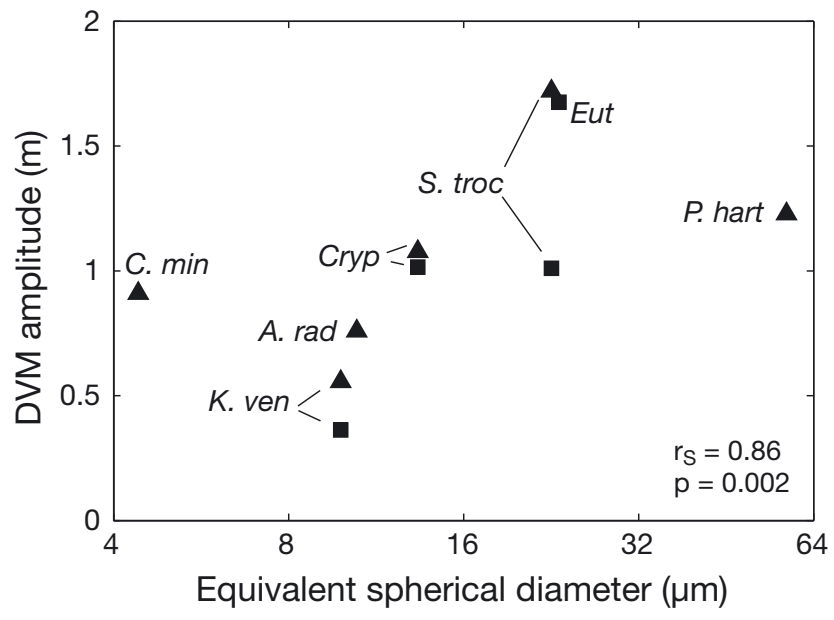

Fig. 8. Relationship between cell size, expressed as equivalent spherical diameter, and amplitude of the center of mass for phytoplankton species that demonstrated statistically significant diel vertical migration during the June (squares) and July (triangles) diel studies. $\mathrm{r}_{\mathrm{S}^{-}}$and $\mathrm{p}$-values are the results from a Spearman's rank correlation between amplitude and diameter. Abbreviations and sources for cell biovolumes used to calculate equivalent spherical diameter are as follows: $A$. $\mathrm{rad}=$ Apedinella radians (Olenina et al. 2006), C. $\min =\mathrm{cf}$. Chroomonas minuta (Campbell 1973), Cryp = Cryptomonas sp. $($ Campbell 1973), Eut = Eutreptia sp. (Olenina et al. 2006), $K$. ven $=$ cf. Karlodinium veneficum (Adolf et al. 2009), $P$. hart $=$ Pheopolykrikos hartmanii (Olenina et al. 2006), S. troc $=$ Scrippsiella trochoidea (Olenina et al. 2006)

enhancement of photosynthetic efficiency (Bergmann et al. 2002) and growth (Rudek et al. 1991, Paerl et al. 1995) upon DIN additions. Therefore, the observed migrations between euphotic surface waters that are deplete in DIN and the more DIN-rich bottom waters at night should enhance growth and productivity of the $\mathrm{N}$-limited resident flagellate community (Lieberman et al. 1994). Within the constraints imposed by light limitation, phytoplankton community composition changes to efficiently exploit the temporal and spatial patterns of nutrient availability (Harris 1980). Given the spatial separation of light and nutrients in the lower NRE, the advantages gained by vertical migration form a basis for the flagellate dominance of the NRE (Pinckney et al. 1998), particularly during the summer months when the severity of $\mathrm{N}$ limitation is greatest (Rudek et al. 1991, Paerl et al. 1995, 2004).

The vertical separation of light and nutrients observed in the present study is common for the lower NRE (Hall 2009) and other stratified aquatic systems when phytoplankton have enough time for uptake of nutrient inputs within the euphotic zone and the primary nutrient source comes from below (Margalef 1978). This certainly is the case for the lower NRE. The virtual lack of flushing by astronomical tides results in a long residence time of $\sim 1$ mo (Pietrafesa et al. 1986), which is enough time for dozens of cell doublings (Pinckney et al. 1997). Lack of tides also results in reduced energy for vertical mixing, permitting long periods of stratification that are disrupted only during strong wind events (Luettich et al. 2000). High net rates of phytoplankton growth upstream effectively filter riverine nutrient loads to the low levels observed in the lower estuary (Pinckney et al. 1997). Our estimates of maximum turnover times for the $\mathrm{NH}_{4}{ }^{+}$pool (the dominant DIN form) in the surface waters of the lower NRE show that phytoplankton and bacteria can deplete surface-water DIN in a few hours. These turnover times for $\mathrm{NH}_{4}{ }^{+}$agree well with the results of previous studies (Christian et al. 1991, Boyer et al. 1994, Twomey et al. 2005), but it should be noted that none of these studies accounted for isotopic dilution. As a result, their data are also likely to overestimate the turnover time of the $\mathrm{NH}_{4}{ }^{+}$pool. With a small $\mathrm{NH}_{4}{ }^{+}$ pool and high $\mathrm{NH}_{4}{ }^{+}$demand, remineralization and uptake rates must be near steady state to maintain a relatively constant $\mathrm{NH}_{4}{ }^{+}$pool in the surface waters of the lower NRE.

The sediments are the major source of 'new' $\mathrm{NH}_{4}{ }^{+}$to the lower NRE during the summer (Luettich et al. 2000). The accumulation of $\mathrm{NH}_{4}{ }^{+}$and $\mathrm{PO}_{4}{ }^{3-}$ below the pycnocline indicates that vertical mixing across the pycnocline is weak and also suggests that light levels below the pycnocline are too low to support net growth of phytoplankton. Our primary productivity measurements support this view. Assimilation in the bottom waters was 10 and $23 \%$ of $P^{\mathrm{B}}{ }_{\max }$ for the June and July midday productivity assays, respectively. Phytoplankton respiration rates are generally 10 to $30 \%$ of $P^{\mathrm{B}}$ max (Cole et al. 1992, Falkowski \& Raven 1997) and for dinoflagellates this ratio is generally $>25 \%$ (Geider \& Osborne 1989). Thus, net production of a dinoflagellate-rich phytoplankton community confined to the bottom waters of the NRE would likely be negative. Light attenuation in the NRE (Woodruff et al. 1999) and in many other estuaries (Cloern 2001) is dominated by background attenuation due to non-algal suspended particulates and colored dissolved organic matter rather than phytoplankton. High background attenuation and lack of tidal mixing are 2 system-specific attributes (sensu Cloern 2001) that set the stage for the vertically separated light and nutrient condition common to the lower NRE.

The observed high degree of vertical phytoplankton patchiness created by vertically migrating flagellates challenges currently accepted views on the relationship between primary productivity and light in this shallow system. Mallin \& Paerl (1992) argued that mixing in the NRE enhanced primary productivity by alleviating both photoinhibition by near-surface irradiances and light limitation of near-bottom irradiances. 
This is probably true during wind mixing events, which occur often within the NRE, but does not reflect the average condition for most of the lower NRE. Their study was conducted along the shallow ( $\sim \mathrm{m})$ margins of the estuary above the pycnocline, where temperature data did appear to indicate predominantly wellmixed conditions. Besides the fact that temperature is a poor predictor of water column stability in the NRE (Christian et al. 1991, Hall 2009), a large portion of the lower NRE is deeper (Fear et al. 2004) and salinitybased stratification occurs more often than well-mixed conditions, particularly during the summer (Luettich et al. 2000, Hall 2009). Additionally, our results clearly demonstrate that, even within the upper mixed layer, mixing is not always sufficient to overcome the swimming velocities of the flagellates.

\section{Vertical migration responses to fluctuations in the growth environment}

The higher daytime ascents of several dominant flagellates on 19 July 2001 mitigated transient light limitation of photosynthesis imposed by dense cloud cover. The validity of this conclusion relies on the accurate estimation of the photosynthetic parameters $(\alpha$ and $P_{\text {max }}^{\mathrm{B}}$ ) of the hyperbolic tangent model (Jassby \& Platt 1976) describing the relationship between PAR and carbon fixation. Although the hyperbolic tangent model fit the data well $\left(\mathrm{R}^{2}=0.92\right)$, the range of PAR values at the depths measured did not produce a clear saturation response on photosynthesis (Fig. 4A). This has little effect on estimation of the slope of the lightlimited portion of the curve $(\alpha)$ but can lead to inaccurate estimation of the maximum biomass-specific productivity $\left(P^{\mathrm{B}}{ }_{\max }\right)$ and, consequently, the level of PAR that saturates photosynthesis (MacIntyre et al. 2002). Both the estimated $\alpha\left(0.0106 \mu \mathrm{g} \mathrm{C} \mu \mathrm{g}\right.$ chl $a^{-1} \mu \mathrm{mol}$ photons $\left.\mathrm{m}^{-2} \mathrm{~s}^{-1} \mathrm{~h}^{-1}\right)$ and $P^{\mathrm{B}}{ }_{\max }\left(7.73 \mu \mathrm{g} \mathrm{C} \mu \mathrm{g} \mathrm{chl} a^{-1} \mathrm{~h}^{-1}\right)$ fell very close to median values reported from other studies of the relationship between PAR and photosynthesis on natural assemblages in the NRE (Boyer et al. 1993, Bergmann et al. 2002, Gaulke et al. 2010). Further, in these 3 studies, light saturation of photosynthesis occurred at levels below the highest observed mean PAR flux during an incubation in the present study (866 $\mu \mathrm{mol}$ photons $\mathrm{m}^{-2} \mathrm{~s}^{-1}$ ). Hence, significant increases in $P^{\mathrm{B}}$ beyond those measured at $866 \mu \mathrm{mol}$ photons $\mathrm{m}^{-2} \mathrm{~s}^{-1}$ were highly unlikely and we feel that $P_{\text {max }}^{\mathrm{B}}$ is reasonably constrained.

Phytoflagellates are capable of acclimating to decreases in PAR flux over time scales of hours in culture studies (Richardson et al. 1983). However, the consistent relationship between PAR and productivity between these 2 days, despite greatly varying incident
PAR, suggests that the flagellate-dominated phytoplankton community did not show strong signs of photoacclimation. During daylight hours, the flagellates formed aggregations that provided access to light while generally avoiding potentially damaging high near-surface irradiances. Avoidance of excessive irradiance may explain the midday descents of Scrippsiella trochoidea and cf. Gymnodinium danicans (Fig. 5DD-FF, LL-NN) on 13 June 2001, a sunny day (Blasco 1978, Passow 1991). These observations are consistent with the increasingly supported theory that, in poorly mixed systems, vertical migration is a primary means for flagellates to cope with short-term (hours to days) changes in irradiance that are detrimental for growth (Passow 1991, Ault 2000).

Near-surface aggregation of phytoflagellates in response to low incident irradiance has been subsequently documented in the NRE. On 19 October 2006, an overcast day with highly stratified water column conditions, a dense surface aggregation of flagellates dominated by the toxic dinoflagellate Karlodinium veneficum (>200000 cells $\mathrm{ml}^{-1}$ ) was discovered just upstream from NR 120. Supersaturated dissolved oxygen conditions ( $180 \%$ saturation) at the surface demonstrated that the flagellates were highly productive (Hall et al. 2008). Given the high proportion of flagellated phytoplankton in the lower NRE (Pinckney et al. 1998) and the near-weekly frequency of frontal systems that bring heavy cloud cover to the region (Litaker et al. 2002), this type of near-surface aggregation may be a common and important mechanism leading to enhanced productivity within the NRE. By contrast, in the nearby well-mixed Newport River Estuary, light reduction because of cloud cover was shown to have a strong negative impact on the growth of dinoflagellates, which were not able to maintain favorable near-surface aggregations against tidal vertical mixing (Litaker et al. 2002).

DVM patterns are also often modified to reflect changes in vertical gradients of limiting nutrients. Experimental studies have shown a general tendency for flagellates to move deeper and spend more time at depth in response to nutrient limitation (Heaney \& Eppley 1981, Cullen 1985, Watanabe et al. 1991, MacIntyre et al. 1997). On 18 to 19 July 2001, bottom-water DIN concentrations were substantially lower than during 12 to 13 June, although surface-water DIN concentrations were similar $(\sim 1 \mu \mathrm{M})$. All 3 of the flagellates that displayed significant DVM behaviors on both days (Scrippsiella trochoidea, cf. Karlodinium veneficum and Cryptomonas sp.) showed deeper migrations in July compared with June (Figs. 5 \& 7). Additionally, cf. Chroomonas minuta also displayed nocturnal population maxima below the pycnocline in July whereas in June, population maxima were restricted to the region 
at or above the pycnocline (Figs. $5 \& 7$ ). These field observations corroborate the results of previous experimental laboratory studies that suggest that these intraspecific variations in DVM patterns provide a strong link between nutritional state and fluctuations in the light and nutrient environment at time scales relevant to the growth of individual cells (Cullen 1985, Passow 1991, MacIntyre et al. 1997, Ralston et al. 2007).

\section{Productivity enhancement via interspecific variation in migration patterns}

Productivity of this estuary is likely enhanced by interspecific differences in the vertical migration patterns of the resident flagellates. In terrestrial plant communities, partitioning of light and nutrient gradients via interspecific differences in rooting depth and canopy height are believed to reduce interspecific competition, increase efficiency of resource use and increase ecosystem productivity (McKane et al. 1990, Hooper et al. 2005, Cardinale et al. 2007). The observed interspecific differences in DVM amplitudes within the NRE are the pelagic analogs of rooting depth and canopy height. We expect that such similar vertical niche diversification within the estuarine light and nutrient gradients should lead to higher resourceuse efficiency and productivity, particularly given the observed positive relationship between cell size and DVM amplitudes.

The observed relationship between cell size and DVM amplitude has been previously documented by comparing maximum DVM amplitudes for dozens of species observed within multiple freshwater and marine systems (Sommer 1988). However, to our knowledge, the present study presents the first evidence of this relationship within a single community of vertically migrating flagellates. The relationship between size and DVM amplitude is partly explained by the fact that smaller size comes at the cost of increased relative water viscosity, which reduces swimming speed (Sommer 1988, Kamykowski et al. 1992). However, directed motility in the form of DVM amplitudes shows an even stronger relationship with cell size than with maximum swimming speed (Sommer 1988). This indicates that DVM amplitude likely covaries with correlates of cell size other than maximum swimming speed. Efficiency of light and nutrient utilization is a likely covariate of cell size that can explain the observed strong relationship between DVM amplitude and cell size in the NRE and across multiple aquatic systems (Sommer 1988). Large cells are less efficient at capturing light and nutrient resources at low levels of resource availability (Fogg 1991, Sunda \& Hardison 2007, Gaulke et al. 2010). The tradeoff between effi- ciency of resource utilization and the ability to access depth layers with higher light and nutrient levels is thus optimized when large cells fulfill their swimming potential to provide daily access to water layers with higher levels of growth-limiting light and nutrient resources (Hecky \& Kilham 1974, Sommer 1988). Optimization of this tradeoff should reduce interspecific competition with the flagellate community, and this niche complementarity would be expected to increase the overall resource-use efficiency and productivity of the NRE and similarly stratified aquatic systems (Hooper et al. 2005).

Productivity enhancement via interspecific variation in vertical migration patterns would then provide a strong linkage between diversity and productivity within poorly mixed aquatic systems. The relationship between biodiversity and productivity in aquatic systems is receiving increasing attention because of changes in diversity associated with species introductions and extinctions, cultural eutrophication and climate change (Hooper et al. 2005, Bracken \& Stachowicz 2006). However, conclusions drawn from laboratory and field studies about the influence of diversity on productivity of phytoplankton communities are often contradictory, and the functional traits within phytoplankton communities that can produce a positive relationship between diversity and productivity are still unclear (Striebel et al. 2009).

Laboratory experiments have often demonstrated that phytoplankton diversity is less important than the presence of one or more highly productive dominant species, i.e. a selection effect (Weis et al. 2007, Schmidtke et al. 2010). In contrast, a field study in a Portuguese estuary found that diversity was correlated with biomass-specific productivity and suggested niche complementarity as the mechanism (Duarte et al. 2006). Similarly, a study of hundreds of Scandinavian lakes and coastal Baltic Sea sites found a strong relationship between nutrient-use efficiency and generalevel phytoplankton richness, suggesting that, across a wide range of natural systems, phytoplankton diversity does contribute to enhanced production (Ptacnik et al. 2008).

Taxon-specific differences in accessory pigments with unique absorption spectra have been identified as one functional trait linking diversity to productivity. As diversity increases, niche complementarity provided by a more diverse suite of photopigments affords a more complete harvest of the solar spectrum for photosynthesis, resulting in higher biomass-specific rates of photosynthesis and growth (Striebel et al. 2009). As another mechanism that can produce niche complementarity (Olli et al. 1998, present study), DVM may also help explain the observed discrepancy between field and laboratory studies of biodiversity and pro- 
ductivity. The cited laboratory experiments were conducted in well-mixed containers (Weis et al. 2007, Schmidtke et al. 2010) that cannot represent the spatial, particularly vertical, resource heterogeneity of natural aquatic systems. It is exactly these gradients upon which interspecific variation in migration patterns would lead to niche complementarity and enhanced productivity.

Although most of the common phytoflagellates displayed a significant DVM pattern during at least one of the 2 diel studies, Prorocentrum minimum and cf. Gymnodinium danicans did not. Depths of population maxima were variable for these species but were always observed within the euphotic zone at or above the pycnocline (Fig. 5GG-VV). The question then becomes, how did these species meet nutrient requirements within the nutrient-poor photic zone? During the June diel study, cf. G. danicans virtually disappeared from the water column near midnight (Fig $5 \mathrm{HH}$,II). It is possible that it migrated below the pycnocline on this night, but nocturnal aggregations were missed by the coarser sampling resolution of the bottom waters. However, the data for $P$. minimum clearly suggest that it did not perform DVM even though it possesses this capability under some conditions (Tyler \& Seliger 1981). A high affinity of uptake at low $\mathrm{NH}_{4}{ }^{+}$concentrations (Fan et al. 2003) and mixotrophic feeding (Jeong et al. 2005) may provide sufficient $\mathrm{N}$ to maintain growth during periods of low nutrient availability (Olli et al. 1998). In any case, the co-occurrence of migratory and non-migratory components of phytoflagellate communities is common (Frempong 1981, Jones 1988, Olli et al. 1998) and increases the functional diversity of vertical distribution patterns within phytoplankton communities (Olli et al. 1998).

\section{CONCLUSIONS}

Rapid light attenuation, high nutrient uptake rates and weak vertical mixing combine to produce marked vertical separation of light and nutrient resources in this shallow microtidal estuary. These conditions select for a phytoplankton community dominated by phytoflagellates that use their vertical migration ability to access light and nutrients on a diel basis through DVM. Intraspecific variation in DVM patterns allow resident flagellates to maintain high rates of productivity and growth during short-term (hours to days) resource scarcity. Interspecific variation in DVM patterns is also likely to enhance community-level productivity by spatio-temporally partitioning the water column according to cell size. As larger phytoplankton are generally less efficient at capturing light and nutrient resources at low levels of resource availability, the observed positive relationship between cell size and the amplitude of DVM suggests that resources are allocated within the phytoflagellate community according to cell requirements. We suggest that niche partitioning via interspecific variation in DVM patterns may be an important and underappreciated functional trait that links diversity of the phytoplankton community to enhanced productivity within poorly mixed systems. Phytoplankton diversity and/or productivity experiments that effectively simulate natural light and nutrient gradients will help quantify the importance of vertical niche partitioning in enhancing community-level phytoplankton productivity.

Acknowledgements. We thank L. Twomey, T. Gallo, E. Perdue, V. Wunderly, P. Wyrick, J. Braddy, K. Rossignol, L. Kelly and B. Peierls for technical assistance. Comments and criticism provided by W. Litaker and 3 anonymous reviewers and also P. Tester, M. Alperin, R. Luettich and J. Carstensen greatly improved this work. This research was funded by the North Carolina Department of Environment and Natural Resources and the Lower Neuse River Basin Association (ModMon Project), North Carolina Sea Grant (project R/MER-58), the National Science Foundation (OCE 0726989, 0825466, 0812913) and EPA-STAR project R82867701.

\section{LITERATURE CITED}

Adolf JE, Bachvaroff TR, Place AR (2009) Environmental modulation of karlotoxin levels in strains of the cosmopolitan dinoflagellate, Karlodinium veneficum (Dinophycea). J Phycol 45:176-192

Anderson DM, Stolzenbach KD (1985) Selective retention of two dinoflagellates in a well-mixed estuarine embayment: the importance of diel vertical migration and surface avoidance. Mar Ecol Prog Ser 25:39-50

Arar EJ, Budde WL, Behymer TD (1997) Methods for the determination of chemical substances in marine and environmental matrices. EPA/600/R-97/072, National Exposure Research Laboratory, US Environmental Protection Agency, Cincinnati, $\mathrm{OH}$

Ault TR (2000) Vertical migration by the marine dinoflagellate Prorocentrum triestinum maximizes photosynthetic yield. Oecologia 125:466-475

Bergmann T, Richardson TL, Paerl HW, Pinckney JL, Schofield O (2002) Synergy of light and nutrients on the photosynthetic efficiency of phytoplankton populations from the Neuse River Estuary, North Carolina. J Plankton Res 24: 923-933

Blasco D (1978) Observations on the diel migration of marine dinoflagellates off the Baja California Coast. Mar Biol 46: 41-47

Boyer JN, Christian RR, Stanley DW (1993) Patterns of phytoplankton primary productivity in the Neuse River Estuary, North Carolina, USA. Mar Ecol Prog Ser 97:287-297

$>$ Boyer JN, Stanley DW, Christian RR (1994) Dynamics of $\mathrm{NH}_{4}{ }^{+}$ and $\mathrm{NO}_{3}{ }^{-}$uptake in the water column of the Neuse River Estuary, North Carolina. Estuaries 17:361-371

> Bracken MES, Stachowicz JJ (2006) Seaweed diversity enhances nitrogen uptake via complementary use of nitrate and ammonium. Ecology 87:2397-2403

Campbell PH (1973) Studies on brackish water phytoplank- 
ton. Sea Grant Publication UNC-SG-73-07, University of North Carolina, Chapel Hill, NC

- Cardinale BJ, Wright JP, Cadotte MW, Carroll IT and others (2007) Impacts of plant diversity on biomass production increase through time because of species complementarity. Proc Natl Acad Sci USA 104:18123-18128

Chang J, Carpenter EJ (1985) Blooms of the dinoflagellate Gyrodinium aureolum in a Long Island Estuary: box model of bloom maintenance. Mar Biol 89:83-93

Christian RR, Boyer JN, Stanley DW (1991) Multi-year distribution patterns of nutrients within the Neuse River Estuary, North Carolina. Mar Ecol Prog Ser 71:259-274

Cloern JE (2001) Our evolving conceptual model of the coastal eutrophication problem. Mar Ecol Prog Ser 210: $223-253$

Cole JJ, Caraco NF, Peierls BL (1992) Can phytoplankton maintain a positive carbon balance in a turbid, freshwater, tidal estuary? Limnol Oceanogr 37:1608-1617

Crawford DW, Purdie DA (1992) Evidence for avoidance of flushing from an estuary by a planktonic, phototrophic ciliate. Mar Ecol Prog Ser 79:259-265

Cullen JJ (1985) Diel vertical migration by dinoflagellates: roles of carbohydrate metabolism and behavioral flexibility. Contrib Mar Sci 27:135-152

Denman KL (1977) Short term variability in vertical chlorophyll structure. Limnol Oceanogr 22:434-441

> Dortch Q, Whitledge TE (1992) Does nitrogen or silicon limit phytoplankton production in the Mississippi River plume and nearby regions? Cont Shelf Res 12:1293-1309

Duarte P, Macedo MF, Cancela da Fonseca L (2006) The relationship between phytoplankton diversity and community function in a coastal lagoon. Hydrobiologia 555:3-18

Eppley RW, Holm-Hansen O, Strickland JDH (1968) Some observations of the vertical migration of dinoflagellates. J Phycol 4:333-340

Falkowski PG, Raven JA (1997) Aquatic photosynthesis. Blackwell Science, Malden, MA

> Fan C, Glibert PM, Burkholder JM (2003) Characterization of the affinity for nitrogen, uptake kinetics, and environmental relationships for Prorocentrum minimum in natural blooms and laboratory cultures. Harmful Algae 2:283-299

Fear J, Gallo T, Hall N, Loftin J, Paerl H (2004) Predicting benthic microalgal oxygen and nutrient flux responses to a nutrient reduction management strategy for the eutrophic Neuse River Estuary, North Carolina, USA. Estuar Coast Shelf Sci 61:491-506

Fisher TR, Gustafson AB, Radcliffe GM, Sundberg KL, Stevenson JC (2003) A long-term record of photosynthetically available radiation (PAR) and total solar energy at $38.6 \mathrm{~N}$, 78.2 W. Estuaries 26:1450-1460

Fogg GE (1991) Tansley Review No. 30. The phytoplanktonic way of life. New Phytol 118:191-232

> Fraga F, Pérez FF, Figueiras FG, Ríos AF (1992) Stoichiometric variations of N, P, C and $\mathrm{O}_{2}$ during a Gymnodinium catenatum red tide and their interpretation. Mar Ecol Prog Ser 87:123-134

Frempong E (1981) Diel variation in the abundance, vertical distribution, and species composition of phytoplankton in a eutrophic English lake. J Ecol 69:919-939

> Ganf GG, Oliver RL (1982) Vertical separation of light and available nutrients as a factor causing replacement of green algae by blue-green algae in the plankton of a stratified lake. J Ecol 70:829-844

> Gaulke AK, Wetz MS, Paerl HW (2010) Picophytoplankton: a major contributor to planktonic biomass and primary production in a eutrophic, river-dominated estuary. Estuar
Coast Shelf Sci 90:45-54

Geider RJ, Osborne BA (1989) Respiration and microalgal growth: a review of the quantitative relationship between dark respiration and growth. New Phytol 112:327-341

Glibert PM, Lipschultz F, McCarthy JJ, Altabet MA (1982) Isotope dilution models of uptake and remineralization of ammonium by marine plankton. Limnol Oceanogr 27: $639-650$

> Gowen RJ, Stewart BM, Mills DK, Elliott P (1995) Regional differences in stratification and its effect on phytoplankton production and biomass in the northwestern Irish Sea. J Plankton Res 17:753-769

Hall NS (2009) Effects of the vertical structure of the water column on the phytoplankton in a shallow lagoonal estuary. PhD dissertation, University of North Carolina at Chapel Hill, Chapel Hill, NC

Hall NS, Litaker RW, Fensin E, Adolf JE, Bowers HA, Place AR, Paerl HW (2008) Environmental factors contributing to the development and demise of a toxic dinoflagellate (Karlodinium veneficum) bloom in a shallow, eutrophic, lagoonal estuary. Estuar Coast 31:402-418

> Handy SM, Coyne KJ, Portune KJ, Demir E and others (2005) Evaluating vertical migration behavior of harmful raphidophytes in the Delaware Inland Bays utilizing quantitative real-time PCR. Aquat Microb Ecol 40:121-132

> Happey-Wood CM (1976) Vertical migration patterns in phytoplankton of mixed species composition. Eur J Phycol 11:355-369

> Harris GP (1980) Temporal and spatial scales in phytoplankton ecology. Mechanisms, methods, models and management. Can J Fish Aquat Sci 37:877-900

> Heaney SI, Eppley RW (1981) Light, temperature and nitrogen as interacting factors affecting diel vertical migrations of dinoflagellates in culture. J Plankton Res 3:331-344

> Hecky RE, Kilham P (1974) Environmental control of phytoplankton cell size. Limnol Oceanogr 19:361-366

Hooper FS, Chapin JJ III, Hector A, Inchausti P and others (2005) Effects of biodiversity on ecosystem functioning: a consensus of current knowledge. Ecol Monogr 75:3-35

Jassby AD, Platt T (1976) Mathematical formulation of the relationship between photosynthesis and light for phytoplankton. Limnol Oceanogr 21:540-547

Jeong HJ, Park JY, Nho JH, Park MO and others (2005) Feeding by red-tide dinoflagellates on the cyanobacterium Synechococcus. Aquat Microb Ecol 41:131-143

> Jones RI (1988) Vertical distribution and diel migration of flagellated phytoplankton in a small humic lake. Hydrobiologia 161:75-87

Jones RI (1991) Advantages of diurnal vertical migrations to phytoplankton in sharply stratified, humic forest lakes. Arch Hydrobiol 120:257-266

Kamykowski D, Reed RE, Kirkpatrick GJ (1992) Comparison of sinking velocity, swimming velocity, rotation and path characteristics among six marine dinoflagellate species. Mar Biol 113:319-328

> Kamykowski D, Milligan EJ, Reed RE (1998) Biochemical relationships with the orientation of the autotrophic dinoflagellate Gymnodinium breve under nutrient replete conditions. Mar Ecol Prog Ser 167:105-117

Klausmeier CA, Litchman E (2001) The vertical distribution of phytoplankton in poorly mixed water columns. Limnol Oceanogr 46:1998-2007

> Kononen K, Huttunen M, Hallfors S, Gentien P and others (2003) Development of a deep chlorophyll maximum of Heterocapsa triquetra Ehrenb. at the entrance to the Gulf of Finland. Limnol Oceanogr 48:594-607 
Lieberman OS, Shilo M, Rijn J (1994) The physiological ecology of a freshwater dinoflagellate bloom population: vertical migration, nitrogen limitation, and nutrient uptake kinetics. J Phycol 30:964-971

Litaker W, Duke CS, Kenney BE, Ramus J (1987) Short-term variability and phytoplankton abundances in a shallow tidal estuary. I. Winter and summer. Mar Biol 96:115-121

Litaker RW, Warner VE, Rhyne C, Duke CS, Kenney BE, Ramus J, Tester PA (2002) Effect of diel and interday variations in light on the cell division pattern and in situ growth rates of the bloom-forming dinoflagellate Heterocapsa triquetra. Mar Ecol Prog Ser 232:63-74

Luettich RA, McNinch JE, Paerl HW, Peterson CH and others (2000) Neuse River Estuary modeling and monitoring project stage 1: hydrography and circulation, water column nutrients and productivity, sedimentary processes and benthic-pelagic coupling, and benthic ecology. North Carolina Water Resources Research Institute No. 325- B, North Carolina State University, Raleigh, NC

Luettich RA, Carr SD, Reynolds-Fleming JV (2002) Semidiurnal seiching in a shallow, micro-tidal lagoonal estuary. Cont Shelf Res 22:1669-1681

MacIntyre JG, Cullen JJ, Cembella AD (1997) Vertical migration, nutrition and toxicity in the dinoflagellate Alexandrium tamarense. Mar Ecol Prog Ser 148:201-216

MacIntyre HL, Kana TM, Anning T, Geider RJ (2002) Photoacclimation of photosynthesis irradiance response curves and photosynthetic pigments in microalgae and cyanobacteria. J Phycol 38:17-38

Mallin MA (1994) Phytoplankton ecology of North Carolina estuaries. Estuaries 17:561-574

Mallin MA, Paerl HW (1992) Effects of variable irradiance on phytoplankton productivity in shallow estuaries. Limnol Oceanogr 37:54-62

Mallin MA, Paerl HW, Rudek J (1991) Seasonal phytoplankton composition, productivity and biomass in the Neuse River Estuary, North Carolina. Estuar Coast Shelf Sci 32: $609-623$

Margalef R (1978) Life-forms of phytoplankton as survival alternatives in an unstable environment. Oceanol Acta 1: 493-509

McKane RB, Grigal DF, Russelle MP (1990) Spatiotemporal differences in ${ }^{15} \mathrm{~N}$ uptake and the organization of an oldfield plant community. Ecology 71:1126-1132

Olenina I, Hajdu S, Edler L, Anderson A and others (2006) Biovolumes and size-classes of phytoplankton in the Baltic Sea. HELCOM Baltic Sea Environmental Proceedings No. 106, Helsinki

Olli K, Heiskanen AS, Lohikari K (1998) Vertical migration of autrophic microorganisms during a vernal bloom at the coastal Baltic Sea-coexistence through niche separation. Hydrobiologia 363:179-189

Paerl HW (1987) Dynamics of blue-green algal (Microcystis aeruginosa) blooms in the lower Neuse River, North Carolina: causative factors and potential controls. North Carolina Water Resources Research Institute No. 229, North Carolina State University, Raleigh, NC

Paerl HW (1988) Nuisance phytoplankton blooms in coastal, estuarine, and inland waters. Limnol Oceanogr 33: 823-847

Paerl HW, Mallin MA, Donahue CA, Go M, Peierls BL (1995) Nitrogen loading sources and eutrophication of the Neuse River estuary, NC: direct and indirect roles of atmospheric deposition. UNC Water Resources Research Institute Report No. 291, North Carolina State University, Raleigh, NC
Paerl HW, Pinckney JL, Fear JM, Peierls BL (1998) Ecosystem responses to internal and watershed organic matter loading: consequences for hypoxia in the eutrophying Neuse River Estuary, North Carolina, USA. Mar Ecol Prog Ser 166:17-25

Paerl HW, Valdes LM, Piehler MF, Lebo ME (2004) Solving problems resulting from solutions: the evolution of a dual nutrient management strategy for the eutrophying Neuse River Estuary, North Carolina, USA. Environ Sci Technol 38:3068-3073

Paerl HW, Valdes LM, Joyner AR, Winkelmann V (2007) Phytoplankton indicators of ecological change in the nutrient and climatically-impacted Neuse River-Pamlico Sound system, North Carolina. Ecol Appl 17(Suppl):88-101

Passow U (1991) Vertical migration of Gonyaulax catenata and Mesodinium rubrum. Mar Biol 110:455-463

> Peierls BL, Christian RR, Paerl HW (2003) Water quality and phytoplankton as indicators of hurricane impacts on a large estuarine ecosystem. Estuaries 26:1329-1343

Pietrafesa LJ, Janowitz GS, Chao TY, Weisberg RH, Askari F, Noble E (1986) The physical oceanography of Pamlico Sound. UNC Sea Grant Publication, UNC-SG-WP-86-5, University of North Carolina, Chapel Hill, NC

Pinckney JL, Millie DF, Vinyard BT, Paerl HW (1997) Environmental controls of phytoplankton bloom dynamics in the Neuse River Estuary, North Carolina, USA. Can J Fish Aquat Sci 54:2491-2501

Pinckney JL, Paerl HW, Harrington MB, Howe KE (1998) Annual cycles of phytoplankton community-structure and bloom dynamics in the Neuse River Estuary North Carolina. Mar Biol 131:371-381

Ptacnik R, Solimini AG, Andersen T, Tamminen T and others (2008) Diversity predicts stability and resource use efficiency in natural phytoplankton communities. Proc Natl Acad Sci USA 105:5134-5138

Ralston DK, McGillicuddy DJ, Townsend DW (2007) Asynchronous vertical migration and bimodal distribution of motile phytoplankton. J Plankton Res 29:803-821

Redfield AC (1958) The biological control of chemical factors in the environment. Am Sci 46:205-221

> Richardson K, Beardall JA, Raven JA (1983) Adaptation of unicellular algae to irradiance: an analysis of strategies. New Phytol 93:157-191

> Rothenberger MB, Burkholder JM, Wentworth TR (2009) Use of long-term data and multivariate ordination techniques to identify environmental factors governing estuarine phytoplankton species dynamics. Limnol Oceanogr 54: 2107-2127

Rudek J, Paerl HW, Mallin MA, Bates PW (1991) Seasonal and hydrological control of phytoplankton nutrient limitation in the lower Neuse River Estuary, North Carolina. Mar Ecol Prog Ser 75:133-142

Salonen K, Rosenberg M (2000) Advantages from diel vertical migration can explain the dominance of Gonyostomum semen (Raphidophyceae) in a small, steeply-stratified lake. J Plankton Res 22:1841-1853

> Schmidtke A, Gaedke U, Weithoff G (2010) A mechanistic basis for underyielding in phytoplankton communities. Ecology 91:212-221

> Seliger HH, Carpenter JH, Loftus M, McElroy WD (1970) Mechanisms for the accumulation of high concentrations of dinoflagellates in a bioluminescent bay. Limnol Oceanogr 15:234-245

> Sommer U (1988) Some size relationships in phytoflagellate motility. Hydrobiologia 161:125-131

Sournia A (1982) Form and function in marine phytoplankton. 
Biol Rev Camb Philos Soc 57:347-394

Striebel M, Behl S, Diehl S, Stibor H (2009) Spectral niche complementarity and carbon dynamics in pelagic ecosystems. Am Nat 174:141-147

Sunda WG, Hardison DR (2007) Ammonium uptake and growth limitation in marine phytoplankton. Limnol Oceanogr 52:2496-2506

Twomey LJ, Piehler MF, Paerl HW (2005) Phytoplankton uptake of ammonium, nitrate, and urea in the Neuse River Estuary, NC, USA. Hydrobiologia 533:123-134

Tyler MA, Seliger HH (1981) Selection for a red tide organism: physiological responses to the physical environment. Limnol Oceanogr 26:310-324

Utermöhl H (1958) Zur Vervollkommnung der quantitativen Phytoplanktonmethodik. Mitt Int Ver Theor Angew Limnol 9:1-38

Watanabe M, Kohata K, Kimura T (1991) Diel vertical migration and nocturnal uptake of nutrients by Chattonella anti-

Editorial responsibility: Graham Savidge,

Portaferry, UK qua under stable stratification. Limnol Oceanogr 36: 593-602

Waters RL, Mitchell JG (2002) Centimetre-scale spatial structure of estuarine in vivo fluorescence profiles. Mar Ecol Prog Ser 237:51-63

Weis JJ, Cardinale BJ, Forshay KJ, Ives AR (2007) Effects of species diversity on community biomass production change over the course of succession. Ecology 88:929-939

Welschmeyer NA (1994) Fluorometric analysis of chlorophyll $a$ in the presence of chlorophyll $b$ and pheopigments. Limnol Oceanogr 39:1985-1992

Wetzel RG (2001) Limnology: lake and river ecosystems. Elsevier Academic Press, San Diego, CA

Wetzel RG, Likens GE (1991) Limnological analysis. WR Saunders, Philadelphia, PA

> Woodruff DA, Stumpf RP, Scope JA, Paerl HW (1999) Remote estimation of water clarity in optically complex estuarine waters. Remote Sens Environ 68:41-52

Submitted: July 27, 2010; Accepted: January 8, 2011

Proofs received from author(s): March 2, 2011 